\title{
Interactions of plutons and detachments: a comparison of Aegean and Tyrrhenian granitoids
}

\author{
Laurent Jolivet $^{1}$, Laurent Arbaret ${ }^{2,3,4}$, Laetitia Le Pourhiet ${ }^{1}$, Florent Cheval-Garabédian ${ }^{2,3,4}$, Vincent Roche ${ }^{1}$, \\ Aurélien Rabillard ${ }^{2,3,4}$, and Lö̈c Labrousse ${ }^{1}$ \\ ${ }^{1}$ Institut des Sciences de la Terre Paris, ISTeP UMR 7193, Sorbonne Université, CNRS-INSU, 75005 Paris, France \\ ${ }^{2}$ Université d'Orléans, ISTO, UMR 7327, 45071, Orléans, France \\ ${ }^{3}$ CNRS/INSU, ISTO, UMR 7327, 45071 Orléans, France \\ ${ }^{4}$ BRGM, ISTO, UMR 7327, BP 36009, 45060 Orléans, France
}

Correspondence: Laurent Jolivet (laurent.jolivet@ sorbonne-universite.fr)

Received: 2 February 2021 - Discussion started: 16 February 2021

Revised: 27 April 2021 - Accepted: 30 April 2021 - Published: 16 June 2021

\begin{abstract}
Back-arc extension superimposed on mountain belts leads to distributed normal faults and shear zones interacting with magma emplacement within the crust. The composition of granitic magmas emplaced at this stage often involves a large component of crustal melting. The Miocene Aegean granitoids were emplaced in metamorphic core complexes (MCCs) below crustal-scale low-angle normal faults and ductile shear zones. Intrusion processes interact with extension and shear along detachments, from the hot magmatic flow within the pluton root zone to the colder ductile and brittle deformation below and along the detachment. A comparison of the Aegean plutons with the island of Elba MCC in the back-arc region of the Apennine subduction shows that these processes are characteristic of pluton-detachment interactions in general. We discuss a conceptual emplacement model, tested by numerical models. Mafic injections within the partially molten lower crust above the hot asthenosphere trigger the ascent within the core of the MCC of felsic magmas, controlled by the strain localization on persistent crustal-scale shear zones at the top that guide the ascent until the brittle ductile transition. Once the system definitely enters the brittle regime, the detachment and the upper crust are intruded, while new detachments migrate upward and in the direction of shearing.
\end{abstract}

\section{Introduction}

In the deep parts of orogens, the flow of melts is coupled with ductile deformation and controlled by buoyancy and tectonic forces (Brown, 1994, 2007; Brown and Solar, 1998). Migmatites, which are a weak crustal material as long as they are kept at a high temperature, are the source of magma batches that concentrate within plutons of various sizes. On the other hand, interactions between magmatism and lithospheric deformation, and more specifically interactions of plutons with crustal-scale tectonics, depend first of all upon the rate of magma production and, to a second order, to strain rates. The rate of magma transfer to the crust is indeed so large compared to tectonic strain rates that the construction of plutons is thought in a first approach to be little influenced by the tectonic setting, especially when small plutons are concerned (de Saint Blanquat et al., 2011).

The Miocene Aegean plutons (Figs. 1, 2), emplaced in an extensional context within metamorphic core complexes (MCCs), may however depart from this general behaviour. Despite a moderate volume, they have indeed recorded the complete evolution from syn-tectonic magmatic flow to localized mylonitic deformation along the main detachment (Laurent et al., 2015; Rabillard et al., 2015, 2018; Bessière et al., 2017). All of them moreover show a systematic magmatic and tectonic evolution of the host MCCs with several magmatic pulses and a series of detachments forming sequentially during exhumation (Rabillard et al., 2018). Several of them also show an association of mixed or mingled 

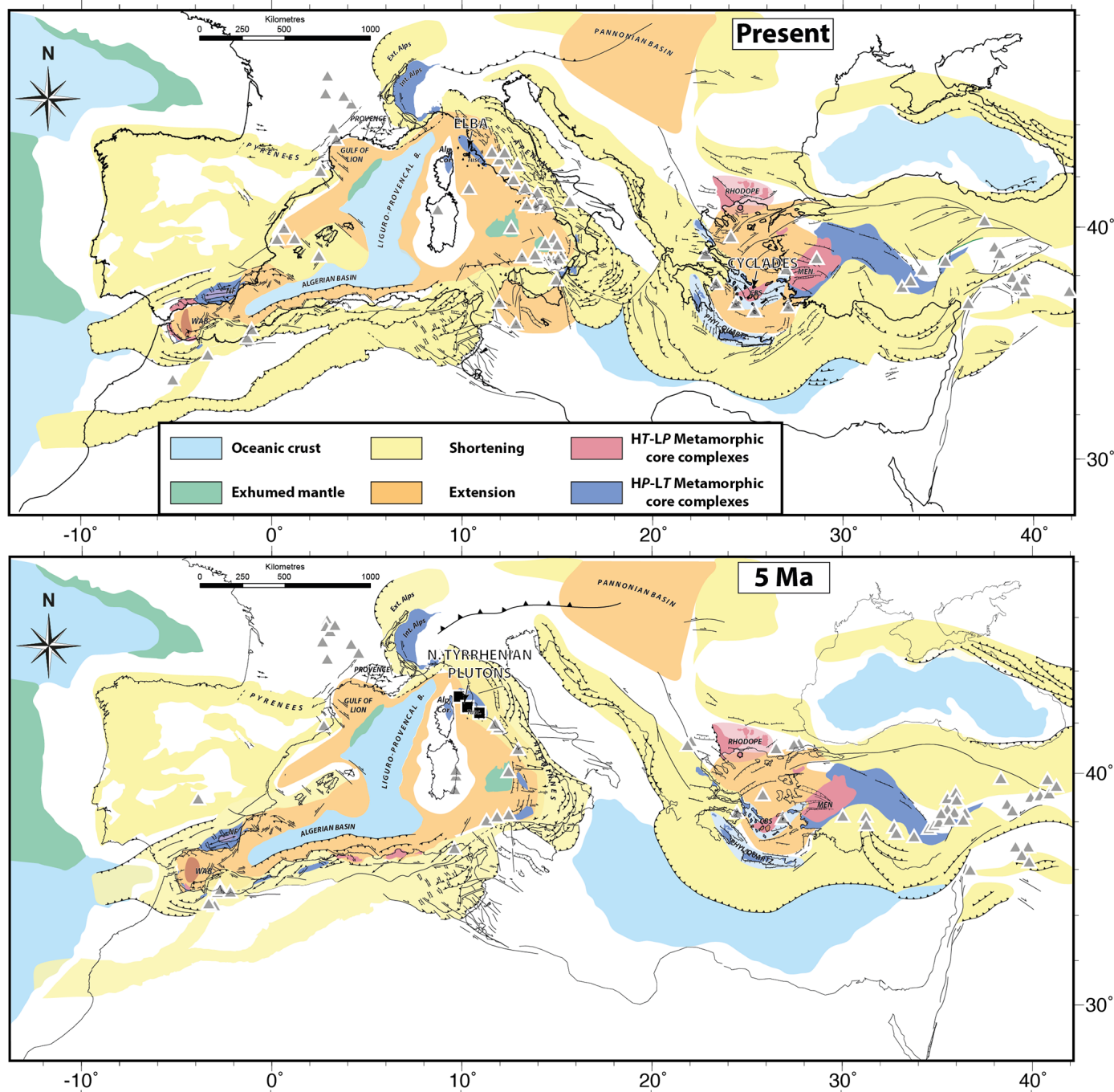

Figure 1. Present-day tectonic context of the Mediterranean region and two reconstructions at 5 and 15 Ma showing the position of volcanic edifices and plutons with an emphasis on the cases of the Cyclades and the island of Elba addressed in this paper. These reconstructions are taken and modified from Romagny et al. (2020). 
felsic and mafic magmas with an evolution from a significant component of crustal melting toward more mafic composition, a trend that is common in post-orogenic magmas (Bonin, 2004).

Whether these features are characteristic of syn-extension plutons in post-orogenic back-arc environments is the question we address in this paper through a comparison of the Aegean plutons with those of the northern Tyrrhenian Sea and Tuscany, with a focus on the island of Elba in the Tuscan Archipelago (Fig. 3). Striking similarities can indeed be observed between the two contexts in terms of tectonic and magmatic evolution. A similar evolution is observed on the Aegean plutons and those of the Tyrrhenian Sea, and we propose a scenario of formation and emplacement of plutons in a back-arc post-orogenic context below crustal-scale detachments.

\section{Geodynamic context}

The Aegean and north Tyrrhenian granitoids were emplaced during the Miocene and part of the early Pliocene in the backarc regions of the Hellenic and Apennine subduction, respectively (Serri et al., 1993; Jolivet et al., 1998, 2015; Pe-Piper and Piper, 2002, 2007; Avanzinelli et al., 2009; Rabillard et al., 2018) (Figs. 2, 3). These two subduction zones started to retreat approximately at the same time 30-35 Myr ago (Jolivet and Faccenna, 2000). A first-order change in the geodynamics of this region did indeed occur at this period, also coeval with the hard collision between Africa and Eurasia in the eastern and westernmost Mediterranean. The subducting African lithosphere, locked between two collision zones, continued to subduct northward but with a significant component of retreat. Since that time subduction has been continuous, with, however, several episodes of slab detachment and tearing (Wortel and Spakman, 2000; Spakman and Wortel, 2004; Faccenna and Becker, 2010; Faccenna et al., 2014). Figure 1 shows the present-day situation as well as two stages at 5 and $15 \mathrm{Ma}$ when the Tyrrhenian and Aegean plutons were forming adapted from the detailed reconstructions by Romagny et al. (2020). Magmatic events are shown with grey triangles (volcanism) and black squares (plutons). The detailed tectonic evolution, the reconstruction method, and the link between magmatism and tectonics are described in discussed in Romagny et al. (2020) and Menant et al. (2016). The progressive retreat of subduction zones and foreland fold-and-thrust belts and/or accretionary wedges is shown to be coeval with crustal thinning and exhumation of metamorphic core complexes. This evolution of the northern Tyrrhenian region as a back-arc basin within the overriding plate of the retreating Apennine subduction is not however entirely unquestioned and alternative models exist which involve different mechanisms, including escape tectonics (Mantovani et al., 2020).
The Aegean plutons studied in this paper were emplaced during the formation of a large tear in the subducting lithosphere between 16 and $8 \mathrm{Ma}$ (Jolivet et al., 2015). The oldest north Tyrrhenian pluton is dated to around $7 \mathrm{Ma}$ in Elba (Westerman et al., 2004), and the youngest ones, Pliocene in age (Serri et al., 1993), are currently exploited for geothermal energy in Tuscany (Rossetti et al., 2008; Rochira et al., 2018). All these plutons contain a significant component of crustal melts and some of them are linked with migmatite domes such as on Naxos, Mykonos and Ikaria (Jansen, 1977; Urai et al., 1990; Denèle et al., 2011; Beaudoin et al., 2015; Vanderhaeghe et al., 2018). Mixing and mingling with mafic magmas are also observed in some of these plutons and the general evolution shows an increase in the mantle component with time.

The geodynamic setting of the northern Tyrrhenian Sea and Tuscany is debated, and the reader is referred to the papers of Mantovani et al. (2020) and Romagny et al. (2020) for opposite views. Since the late 1990s two opposite interpretations have been discussed. One school of thought considers a continuum of extension from the Oligocene to the present with an eastward migration of extension in the back-arc region of the retreating Apennine subduction (Keller and Pialli, 1990; Jolivet et al., 1994, 1998; Faccenna et al., 2001a, b; Brogi et al., 2003, 2005; Brogi, 2008, 2020; Brogi and Liotta, 2008). Extension starts in the early Oligocene between Corsica and Provence and reaches the highest part of the Apennines in the recent period. Extensional basins, controlled by low-angle east-dipping normal faults, migrate eastward following the migration of the magmatic arc. A part of this extension is also accommodated by higher-angle normal faults, most of them dipping eastward, leading to a stretching factor of about 2.2 (Moeller et al., 2013, 2014). The Zuccale low-angle normal fault or an east-dipping ductile extensional shear zone bounding the Monte Capanne pluton, both observed on the island of Elba, are part of this continuum of extension in the late Miocene and the Pliocene (Keller and Pialli, 1990; Daniel and Jolivet, 1995; Collettini and Holdsworth, 2004). This type of model is challenged by an alternative view where extension is only very recent, not dating to before the late Miocene or even later in the Tyrrhenian Sea, and where several basins on the mainland of Italy are instead interpreted as compressional (Finetti et al., 2001; Bonini and Sani, 2002; Ryan et al., 2021). One of the main data sets which is at the root of this debate is the CROP seismic profile crossing the Tyrrhenian Sea, Tuscany and the Apennines (Finetti et al., 2001; Bonini and Sani, 2002; Ryan et al., 2021). Discussions of this alternative can be found developed further in several papers (Brogi et al., 2005; Brogi, 2008, 2020; Brogi and Liotta, 2008). We consider that the compressional model cannot account for the first-order features of the northern Tyrrhenian Sea such as the crustal and lithospheric thickness and the geological evolution of the islands of Corsica, Elba and Giglio, and we deliberately place 


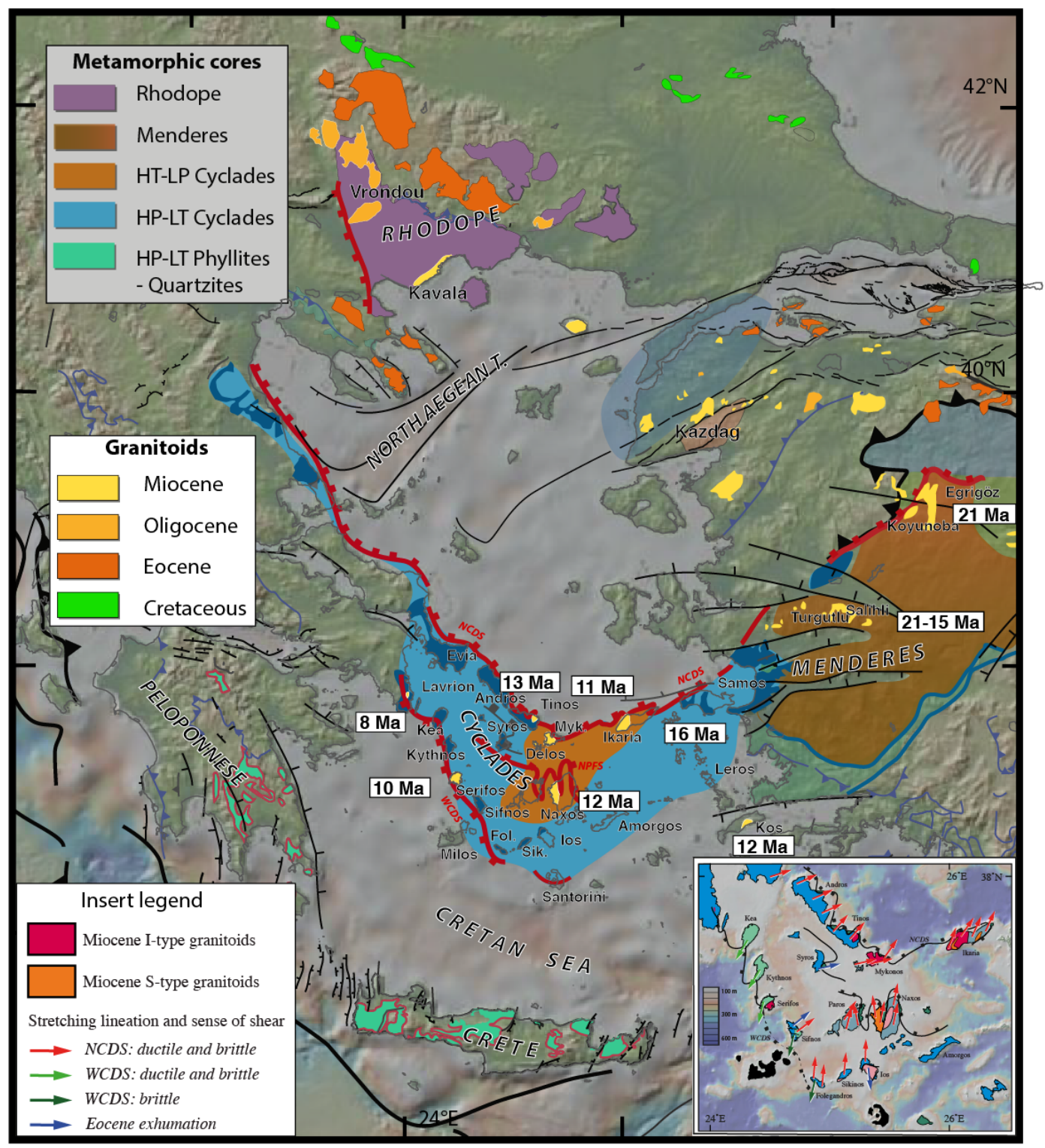

Figure 2. Tectonic map of the Aegean region showing the successive generations of granitoids since the Late Cretaceous. Modified from Jolivet et al. (2015). Background topography was extracted from GeoMapApp.

our research in the framework of the migrating extension models.

Most of these plutons are associated with low-angle normal faults (LANFs) and shear zones, and they were emplaced in the core of MCCs (Faure et al., 1991; Lee and Lister, 1992; Lister and Baldwin, 1993; Daniel and Jolivet, 1995; Jolivet et al., 1998; Rabillard et al., 2018). These LANFs and associated ductile shear zones (we use the term "detachment" for the whole structure, brittle and ductile) started to form before the emplacement of the plutons, in both regions. The main differences between the two regions are the kinematics of these detachments (Figs. 2, 3) (Jolivet et al., 2008) and the role of tectonic inheritance. In the Aegean, most of the MCCs are capped by north-dipping detachments except in the southwest, where south-dipping detachments are observed. The north-dipping detachments probably partly reactivate former thrusts related to the building of the Hellenides orogenic wedge. Whatever the nature (i.e. reactivated structure or not) and the sense of shear of the Aegean detachments, the interaction with the plutons follows a similar pattern that we recall below (see Rabillard et al., 2018, for details). In the northern Tyrrhenian Sea and in Tuscany, all detachments dip eastward, i.e. toward the subduction zone. In that case, the detachments cannot reactivate the former thrusts of the internal Apennines that dip westward. Only in the case of the oldest detachments, found in Alpine Corsica, 

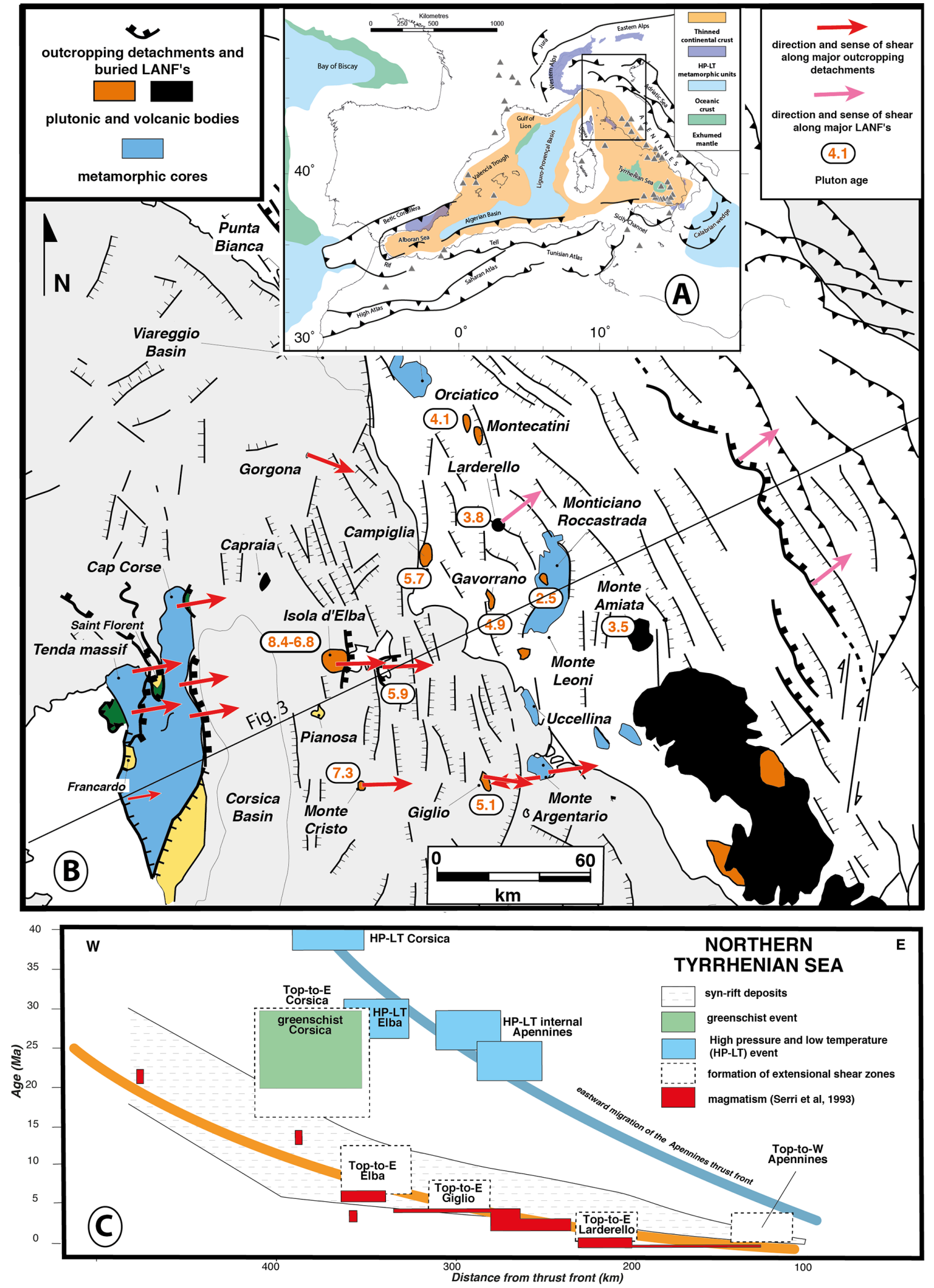

Figure 3. Tectonic map of the central and Western Mediterranean with the distribution of recent magmatism (Savelli, 1988 2002a, b; Serri et al., 1993; Duggen et al., 2005; Avanzinelli et al., 2009; Savelli, 2015). Tectonic map (b) of the northern Tyrrhenian region and Northern Apennines and (c) a diagram showing the evolution of the ages of syn-rift basins, metamorphic events and magmatism along a cross section from Corsica to the Apennines, modified from Jolivet et al. (1998). 
can they correspond to reactivated thrusts. The case of the island of Elba shows very well the detachments cutting downsection eastward within the stack of former nappes (Keller and Pialli, 1990; Collettini and Holdsworth, 2004).

The emplacement of plutons underneath extensional detachments may also be influenced by transfer faults accommodating along-strike variations in the rate of extension. This has been mainly discussed for geothermal reservoirs associated with plutons at the intersection of a detachment and a transfer fault, which leads to enhanced permeability and more efficient advection of fluids toward the Earth surface (Dini et al., 2008; Faulds et al., 2009; Liotta et al., 2015, 2021; Gola et al., 2017; Roche et al., 2018a, b; Brogi et al., 2021). In the case of the Tuscan Archipelago and Tuscany, this possibility has been documented by field studies in eastern Elba and the Gavorrano pluton (Dini et al., 2008; Faulds et al., 2009; Liotta et al., 2015, 2021; Gola et al., 2017; Roche et al., 2018a, b; Brogi et al., 2021). The present paper is however mainly focused on the extensional component of deformation and the interactions between low-angle detachments and the emplacement of plutons.

\section{Aegean plutons}

We first recall the main findings of the interactions between detachments and plutons as documented from the Aegean. The Miocene Aegean and Menderes plutons were emplaced during a short time period between $\sim 20$ and $8 \mathrm{Ma}$, the oldest cropping out in the Menderes massif and the youngest in the western part of the Aegean region (Fig. 2) (Jolivet et al., 2015). Those occupying the Cycladic domain are all associated with detachments, either north- or south-dipping (Fig. 2) (Grasemann and Petrakakis, 2007; Rabillard et al., 2018). Except for Serifos and Lavrion plutons, associated with the West Cycladic Detachment System (WCDS) (Grasemann and Petrakakis, 2007; Berger et al., 2013; Scheffer et al., 2016), the plutons crop out in the core of MCCs exhumed by north-dipping detachments, such as the North Cycladic Detachment System (NCDS) (Gautier and Brun, 1994a, b; Jolivet et al., 2010) or the Naxos-Paros Fault System (NPFS) (Urai et al., 1990; Gautier et al., 1993; Vanderhaeghe, 2004; Bargnesi et al., 2013; Cao et al., 2017). The detachment upper plate is made of the Upper Cycladic Nappe, a remnant of the Pelagonian domain, made of greenschist-facies metabasites or serpentinite with, in a few cases, early to late Miocene sediments deposited during extension (Angelier et al., 1978; Sanchez-Gomez et al., 2002; Kuhlemann et al., 2004; Menant et al., 2013). The MCCs are made of various units of the Cycladic blueschists, more or less retrograded in the greenschist facies, or the Cycladic basement, showing HT-LP (high-pressure and low-temperature) metamorphic facies and even anatectic conditions on several islands, such as Naxos, Paros, Mykonos or Ikaria (Buick and Holland, 1989; Urai et al., 1990; Buick, 1991; Keay et al., 2001;
Duchêne et al., 2006; Seward et al., 2009; Kruckenberg et al., 2011; Beaudoin et al., 2015; Laurent et al., 2015; Rabillard et al., 2015, 2018). The plutons intruded into these MCCs and were sheared at the top by the detachments during their emplacement (Rabillard et al., 2018).

The granitoids show a variety of facies and composition, but most of them have a crustal melting component and some are closely associated with migmatites, as on Ikaria or Mykonos (Denèle et al., 2011; Beaudoin et al., 2015). Compositions show a common trend for these plutons indicating that they crystallized primarily from I-type magmas with some contamination by the continental crust and little fractionation (Fig. A1, Appendix A). Field evidence shows a close association of these I-type intrusions with two-mica granites (in Ikaria for instance), migmatites or both (Ikaria, Naxos, Paros, Rineia-Delos) (Pe-Piper et al., 1997, 2002; PePiper, 2000; Vanderhaeghe, 2004; Bolhar et al., 2010, 2012; Bargnesi et al., 2013; Beaudoin et al., 2015; Laurent et al., 2015; Jolivet et al., 2021). Tinos, Ikaria and Serifos granitoids were emplaced in several magma batches with an evolution through time, characterized by more and more mafic compositions and a decrease in the grain size (Grasemann and Petrakakis, 2007; Ring, 2007; Bolhar et al., 2010, 2012; Petrakakis et al., 2010; de Saint Blanquat et al., 2011; Beaudoin et al., 2015; Laurent et al., 2015; Rabillard et al., 2015; Ducoux et al., 2016). On Serifos and Naxos, the farthest parts of the pluton from the detachment show an enrichment in mafic enclaves and evidence for magma mixing and mingling in the roots of the rising plutons (Rabillard et al., 2015, 2018; Bessière et al., 2017).

A common evolution is observed in several of these plutons during their interaction with the system of detachments exhuming their host MCC (Rabillard et al., 2018). A series of two or three detachments is observed (Figs. 5, 6). The deepest one is mostly ductile and has started to act long before the granitic intrusion that ultimately intrudes it. The upper detachments are mostly brittle and are locally intruded by dykes and sills emanating from the main pluton. When a sedimentary basin is present, it is deposited on top of the uppermost detachment during extension and can be partly affected by mineralized veins (Menant et al., 2013). All plutons show a gradient of shearing deformation toward the detachment with an evolution from ductile to brittle (Fig. 5). The maps shown in Fig. 5 were drawn after detailed field observations and the construction of a scale of up to seven grades of progressive deformation, from non-deformed granitic texture to ultra-mylonites, with the progressive appearance of foliation, stretching lineation, and localization of $\mathrm{C}$ and $\mathrm{C}^{\prime}$ shear bands (Berthé et al., 1979; Lister and Snoke, 1984); for details see Rabillard et al. (2018). The inner parts of the plutons show mixing of acidic and mafic magmas and a co-magmatic deformation co-axial with the post-solidus deformation along the detachment (Rabillard et al., 2015, 2018). The flow of magma is thus oriented by the regional strain field. Serifos shows (i) a decrease in grain size through time with an inner 


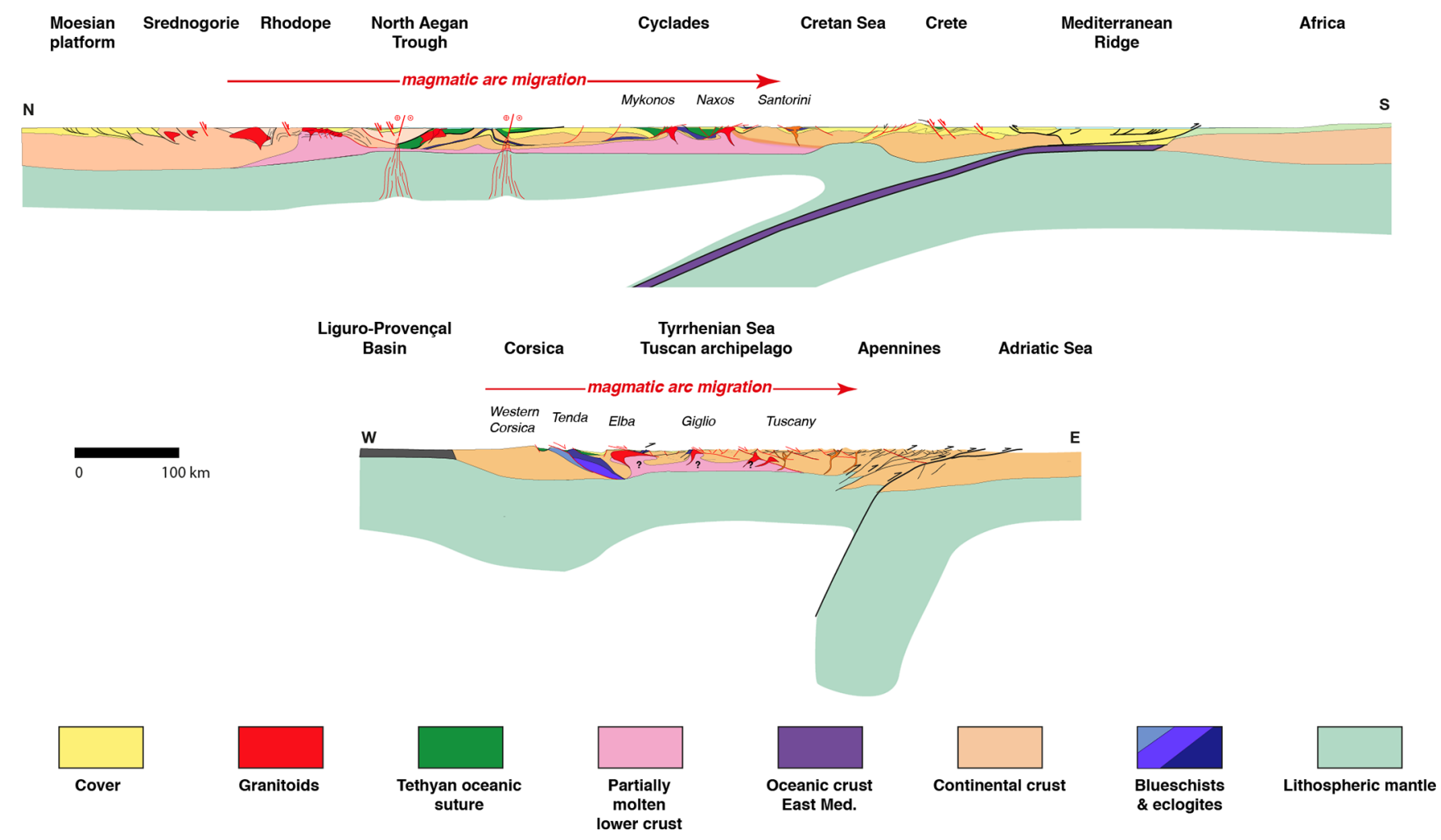

Figure 4. Two lithospheric-scale cross sections of the Aegean domain (Jolivet and Brun, 2010) and the northern Tyrrhenian Sea and the Apennines (Jolivet et al., 1998).

facies with smaller grain size and finally fine-grained dykes and (ii) evidence for hydrothermalism in the root zone of the pluton, suggesting that the magmatic system was open upward with a possible volcano-plutonic system (Rabillard et al., 2015, 2018).

\section{North Tyrrhenian plutons}

We now describe our observations in the Monte Capanne pluton on the island of Elba and place them in the regional tectonic context. The Monte Capanne pluton (Fig. 7) is the oldest of a series of plutons cropping out in the Tuscan Archipelago and onshore Tuscany (Serri et al., 1993; Westerman et al., 2004; Avanzinelli et al., 2009). Among the youngest plutons are those powering the active geothermal fields of Larderello and Monte Amiata (Camelli et al., 1993; Brogi et al., 2003; Rossetti et al., 2008). These plutons belong to magmas migrating from west to east between the end of the Oligocene and the Quaternary, mimicking the migration of the Apennine thrust system and the HT-LP metamorphism of the internal Apennines and Tuscan Archipelago which started earlier at the end of Oligocene (Serri et al., 1993; Jolivet et al., 1998) (Fig. 3). This situation is thus very similar to the Aegean Sea. The decrease in the time lag between the recording of HT-LP metamorphism or the activation age of the thrust front and the magmatism has been interpreted as a consequence of slab steepening during retreat (Jolivet et al., 1998; Brunet et al., 2000). Magmatism is recorded in the Tuscan Archipelago (islands of Capraia, Elba and Giglio) from 8 to 5 Ma with plutons in Elba and Giglio and volcanism in Capraia, and the mantle source of the magma appears highly contaminated by subductionrelated and crustal-derived metasomatic fluids (Gagnevin et al., 2011).

Pluton ages decrease eastward from $\sim 8$ to $2-3 \mathrm{Ma}$ (Fig. 3). The oldest plutons are observed offshore on the islands of Elba (Monte Capanne and Porto Azzuro plutons), Monte Cristo and Giglio (Westerman et al., 1993) (Fig. 3). These four plutons are granodiorites/monzogranites and they all display a contamination with crustal magmas with a main source thought to be lower-crustal anatexis (Serri et al., 1993; Innocenti et al., 1997). They were emplaced within an overall extensional context during the rifting of the northern Tyrrhenian Sea in the back-arc region of the Apennines (Jolivet et al., 1998). First evidenced in Alpine Corsica and on the island of Elba, a series of east-dipping low-angle detachments controlled the kinematics of extension along the CorsicaApennines transect from the Oligocene onward (Jolivet et al., 1998). Extension is shown to migrate from west to east with time, and it is active at present in the highest-altitude regions of the Apennines just west of the Corno Grande peak with, however, west-dipping normal faults (D'Agostino 

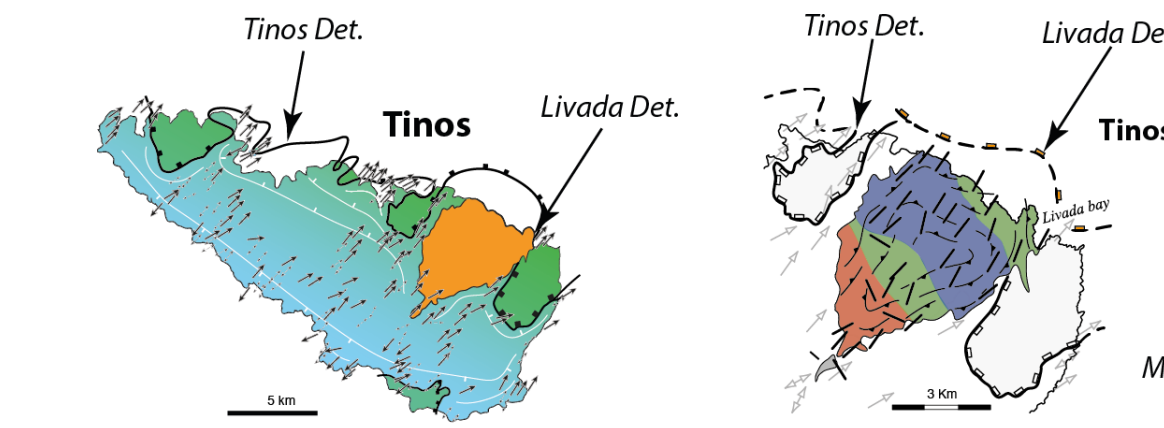

\section{|N \\ Livada\&}

Mykonos
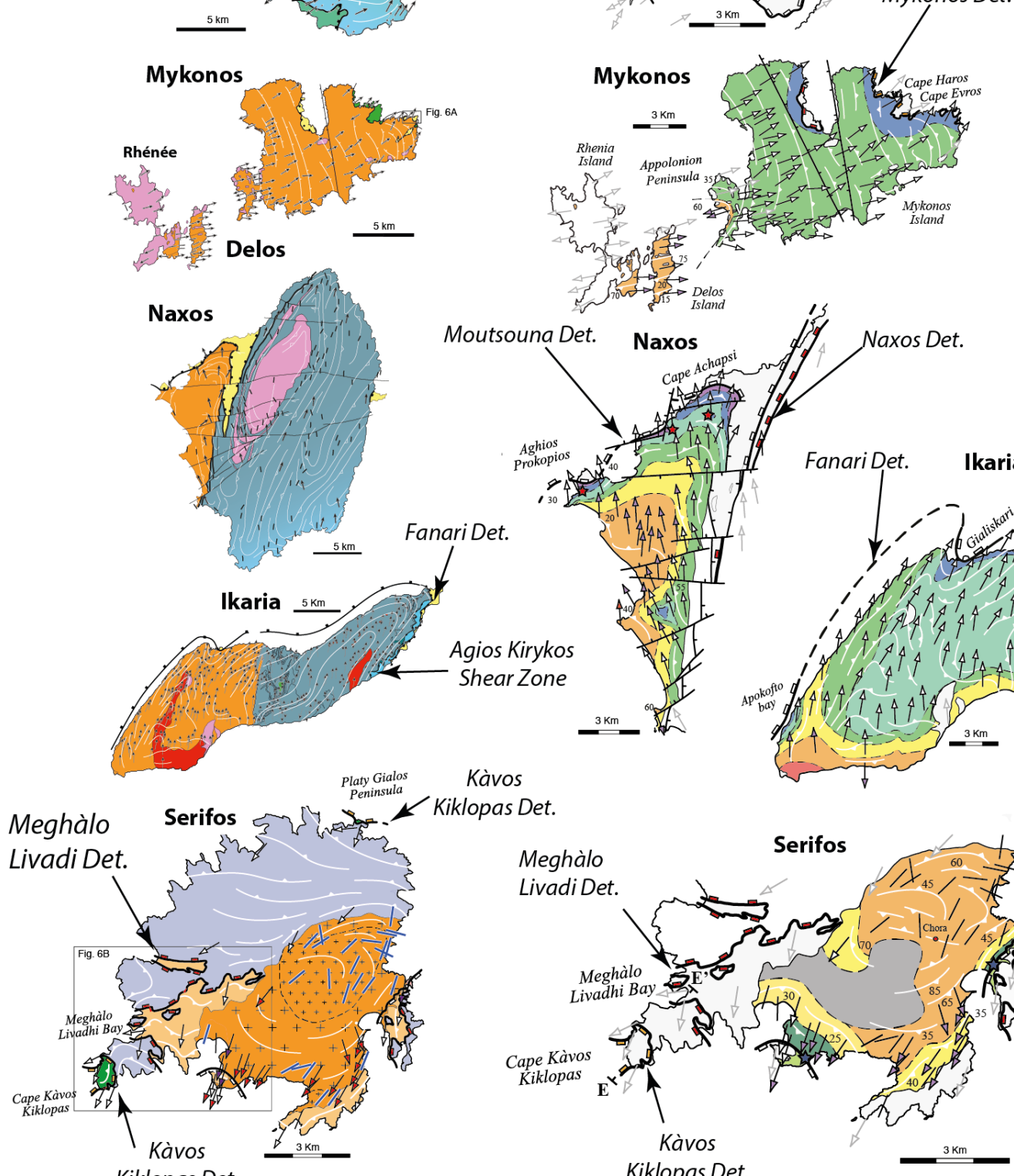

Kiklopas Det.

Agios Kirykos
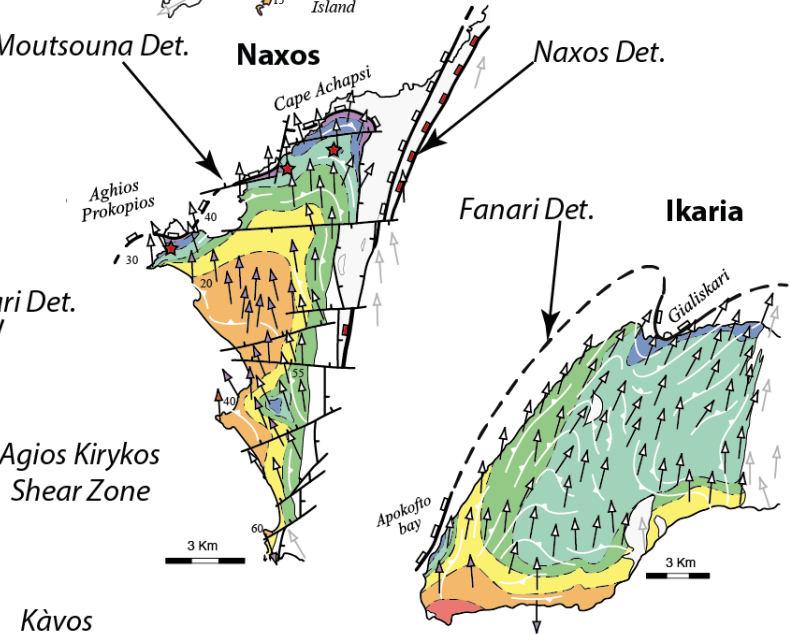

Kiklopas Det.
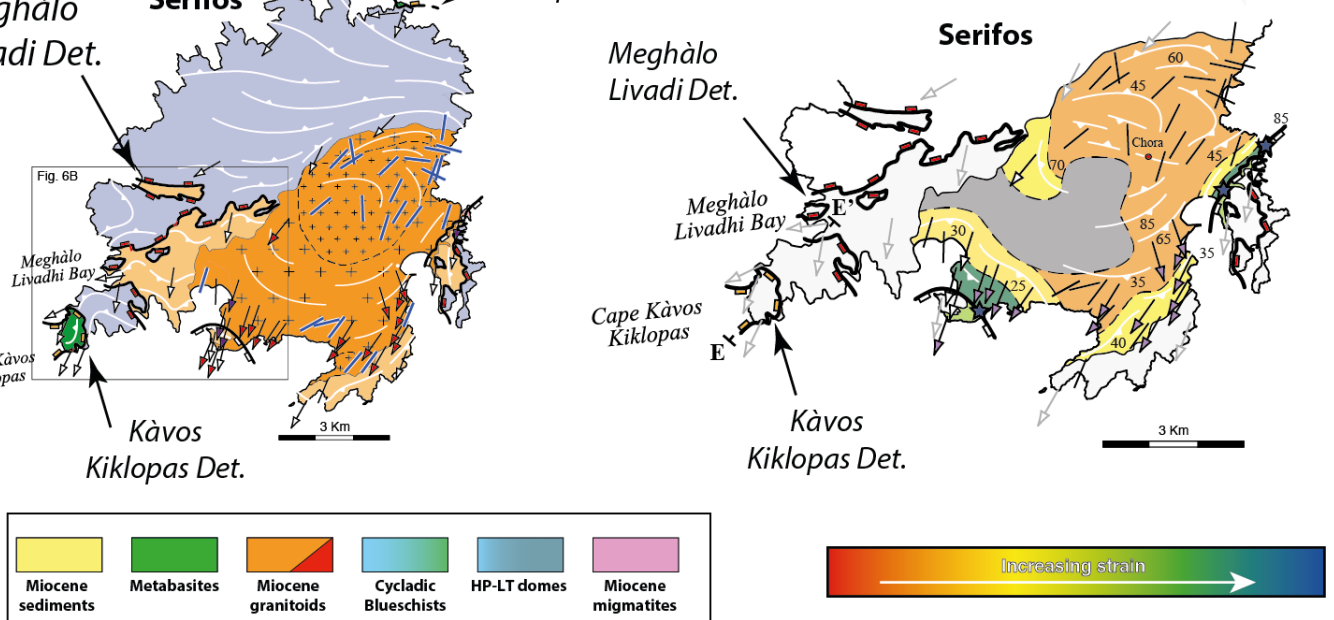

Figure 5. Five examples of the Aegean granitoids showing the interactions between deformation and intrusion, after Rabillard et al. (2018) and references therein. Maps of the left column show maps of the entire islands, and the right column shows the internal fabrics of the plutons. These maps were obtained based on deformation grades observed in the field; a scale of grades was designed for each pluton to describe the gradients. Arrows show stretching lineations and the sense of shear, and black bars on the Tinos pluton show the direction of the magnetic lineation. 


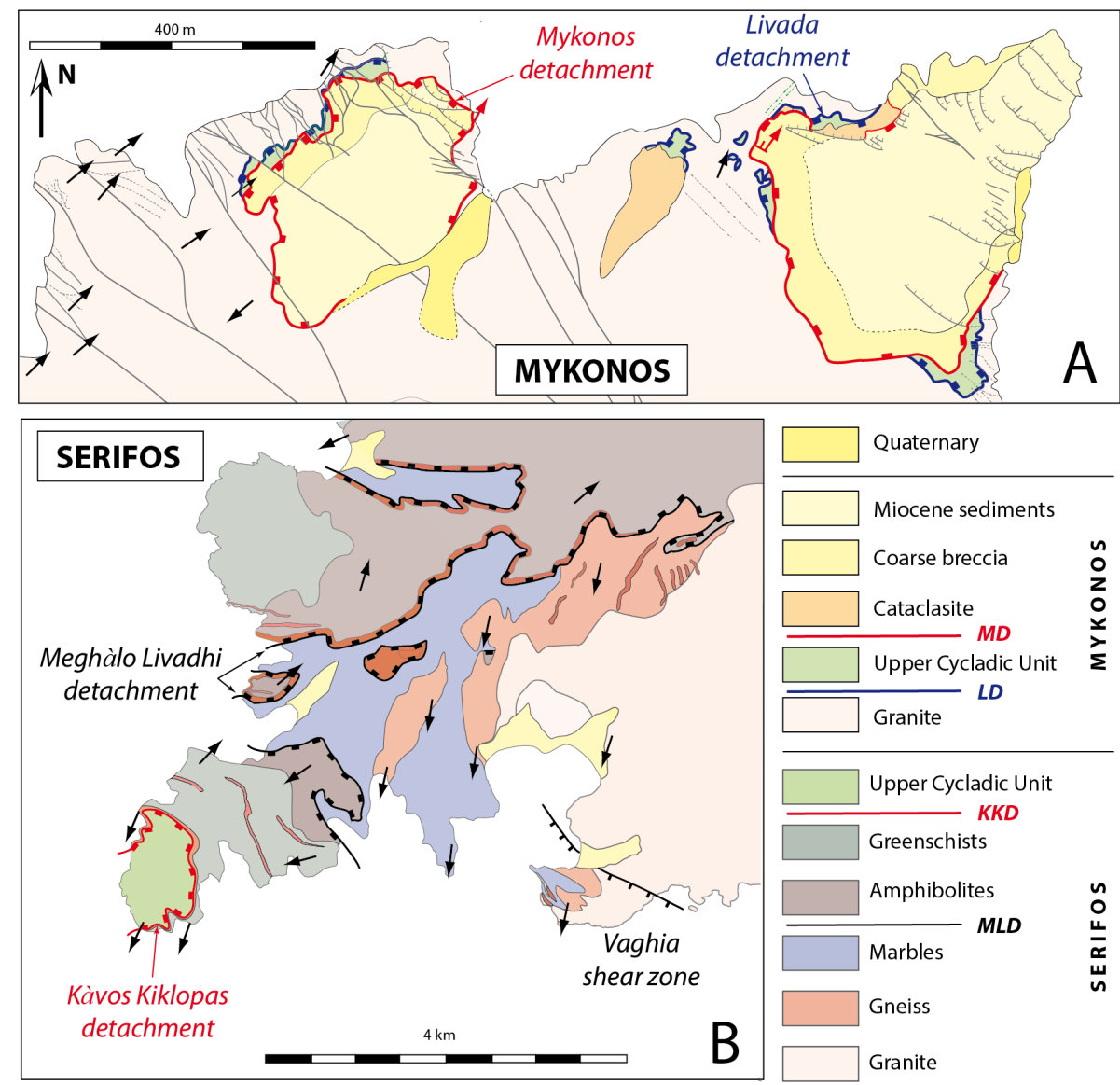

Figure 6. Details of the two detachments on Mykonos and Serifos. (a) Northeastern Mykonos (see location in Fig. 5); (b) southwest Serifos. The Mykonos (MD) and Livada (LD) detachments on Mykonos and the mineralized veins and normal faults (baryte and iron hydroxides) grey - are after Menant et al. (2013). The Kàvos Kiklopas (KKD) and Meghàlo Livadi (MLD) detachments on Serifos are after Grasemann and Petrakakis (2007) and Ducoux et al. (2016).

et al., 1998). The youngest east-dipping low-angle normal faults are seismically active in the Alto Tiberina region (Collettini and Barchi, 2002, 2004; Pauselli and Ranalli, 2017). Evidence for top-to-the-east-shearing deformation is found within the plutons of the Tuscan Archipelago, but the detachments crop out nicely mostly on the island of Elba (Keller and Pialli, 1990; Collettini and Holdsworth, 2004; Liotta et al., 2015).

However, another vision that stems from different interpretations of the observed top-to-the-east shear zones in eastern Elba in the vicinity of the Zuccale Detachment, is proposed for the emplacement of those plutons. Detailed studies have documented the progressive deformation along these shear zones from brittle to ductile and the HT-LP conditions associated with the most ductile ones, and they have been dated from the Pliocene (Daniel and Jolivet, 1995; Mazzarini et al., 2011; Musumeci and Vaselli, 2012; Musumeci et al., 2015; Massa et al., 2017; Papeschi et al., 2017, 2018; Viola et al., 2018; Papeschi et al., 2019). Their interpretation can then be debated. They can either be west-dipping thrusts or back-tilted top-to-the-east extensional ductile shear zones coeval with the progressive localization of the Zuccale Detachment, which is our interpretation following Daniel and Jolivet (1995), Mazzarini et al. (2011), Musumeci and Vaselli (2012), Musumeci et al. (2015), Massa et al. (2017), Papeschi et al. (2017, 2018, 2019), and Viola et al. (2018).

\subsection{Monte Capanne pluton on the island of Elba}

Elba, the largest island of the Tuscan Archipelago, shows the relations between peraluminous magmatic bodies and two east-dipping low-angle shear zones cutting down-section within the Tuscan nappe stack emplaced before extension started (Fig. 7) (Keller and Pialli, 1990; Bouillin et al., 1993; Pertusati et al., 1993; Daniel and Jolivet, 1995; Westerman et al., 2004; Bianco et al., 2015). Five thrust packages (complexes I to V) are separated by west-dipping low-angle reverse faults (Trevisan, 1950; Barberi et al., 1967; Perrin, 1975; Pertusati et al., 1993; Bianco et al., 2015, 2019). Long thought free of any HT-LP imprint, at variance with the nearby islands of Gorgona and Giglio, the nappe stack has 


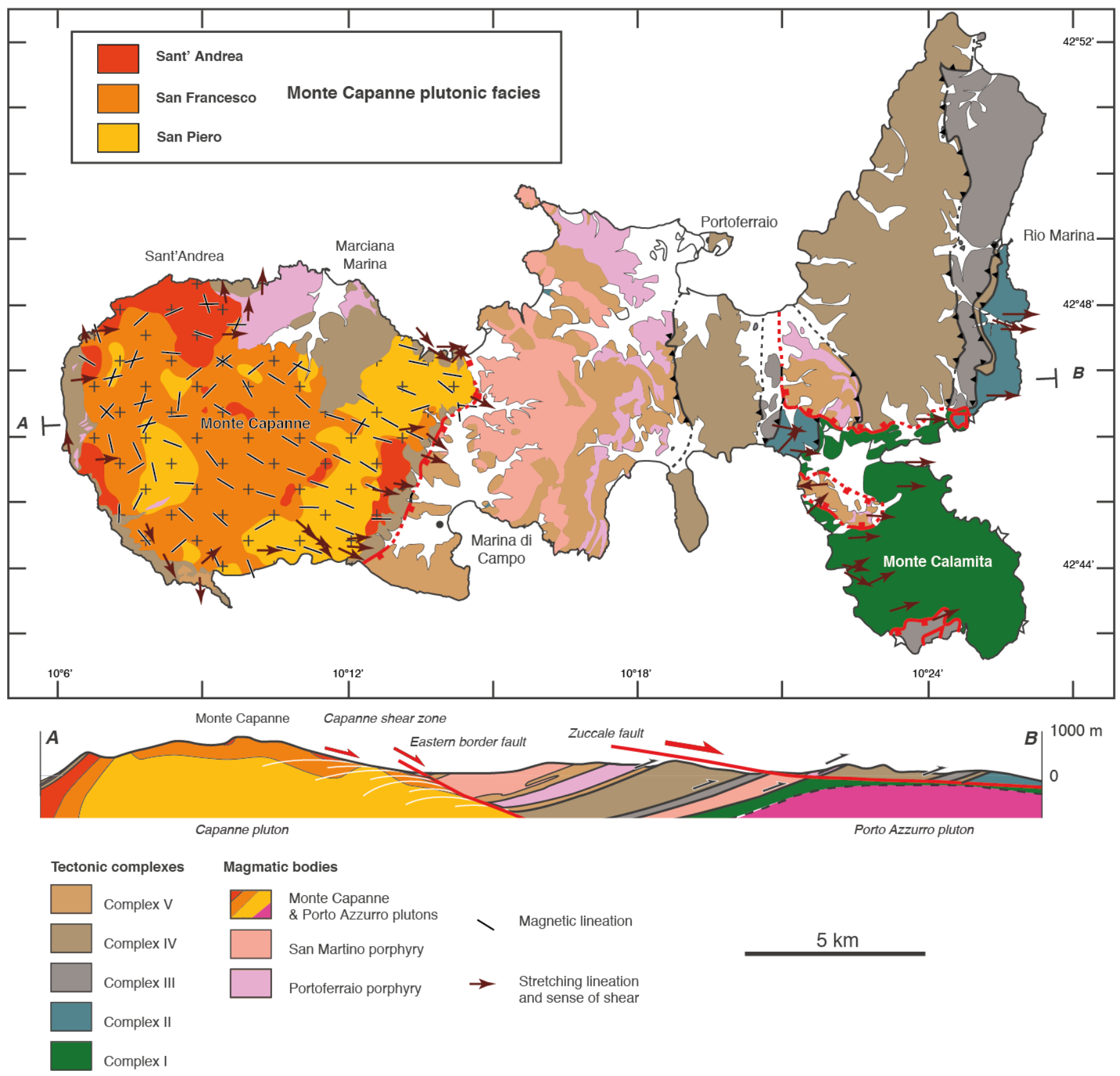

Figure 7. Tectonic map and cross section of the island of Elba showing the main tectonic units and the main extensional shear zones and detachments, modified after Bianco et al. (2015). Details of the internal structure of the Monte Capanne intrusions are reported based on Farina et al. (2010).

recently revealed HT-LP parageneses along the east coast of the island (Bianco et al., 2015). Through a correlation with the HT-LP units of Gorgona (Rossetti et al., 1999), where ${ }^{40} \mathrm{Ar} /{ }^{39} \mathrm{Ar}$ dating on micas yielded ages of around $25 \mathrm{Ma}$ (Brunet et al., 2000), the Elba blueschists were attributed to the late Oligocene and early Miocene, which was recently confirmed with ${ }^{40} \mathrm{Ar} /{ }^{39} \mathrm{Ar}$ ages around $20 \mathrm{Ma}$ (Bianco et al., 2019).
The Nappe stack is intruded by the shallow-level San Martino and Portoferraio porphyries coeval with the Monte $\mathrm{Ca}$ panne pluton (Fig. 7), spanning a short period between 8 and 6.8 Ma, showing that the magma intruded into the detachment at a late stage (Saupé et al., 1982; Juteau et al., 1984; Ferrara and Tonarini, 1985; Bouillin et al., 1994; Westerman et al., 2004). The Monte Capanne intrusion makes up the major part of the western half of the island and the highest peak. It is surrounded by a contact metamorphic aureole developed 

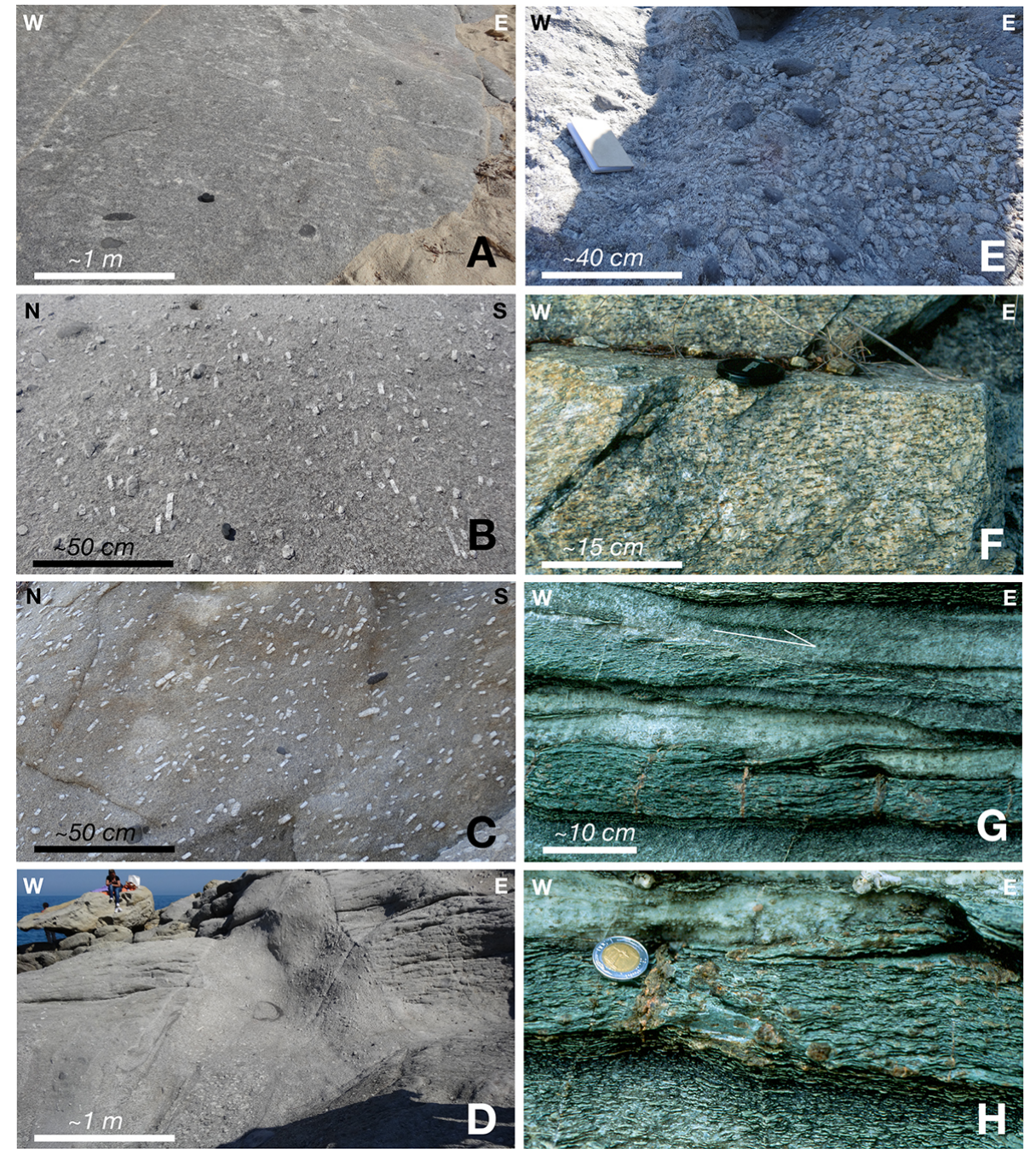

Figure 8. Photographs of the Sant'Andrea facies in the Monte Capanne pluton and of the deformation along the eastern margin of the pluton, in the pluton itself and in the contact metamorphic aureole. (a) General view of the orientation of K-feldspar megacrysts and some mafic enclaves. (b) Detailed view of the oriented K-feldspar megacrysts (horizontal plane). (c) Zoom on the orientation of K-feldspar megacrysts (vertical plane). (d) Cotoncello dyke. (e) Cluster of K-feldspar megacrysts in the vicinity of the Cotoncello dyke. (f) Mylonitic foliation within the Monte Capanne shear zone. (g) Sigmoidal foliation and top-to-the-east sense of shear within the metamorphic aureole of the Monte Capanne pluton. (h) Detailed view of syn-kinematic contact metamorphism garnets in veins perpendicular to the regional stretching direction.

at the expense of the nappe stack (Duranti et al., 1992; Dini et al., 2002; Rossetti et al., 2007; Rossetti and Tecce, 2008). The metamorphic parageneses within the aureole suggest an emplacement at a depth of 4-5 km (Dini et al., 2002; Rocchi et al., 2002; Farina et al., 2010; Pandeli et al., 2018). The pluton shows an internal deformation with a gradient of shearing toward the east attested by the magnetic fabric, stretching lineation and sense of shear (Bouillin et al., 1993; Daniel and Jolivet, 1995). The pluton and the metamorphic aureole are separated from the nappe stack by an east-dipping low-angle shear zone (Capanne shear zone) evolving into a brittle east-dipping fault (eastern border fault) (Daniel and Jolivet, 1995). Syn-kinematic contact metamorphism miner- als coeval with top-to-the-east kinematic indicators attest for the syn-kinematic nature of the intrusion (Daniel and Jolivet, 1995; Pandeli et al., 2018).

The eastern part of the island shows granitic dykes emanating from the buried younger Porto Azzuro pluton intruding the Calamiti schist complex (Complex I, Fig. 7) (Daniel and Jolivet, 1995; Maineri et al., 2003; Musumeci and Vaselli, 2012). Here too, evidence for top-to-the-east shearing at the time of intrusion has been described (Daniel and Jolivet, 1995) (Fig. 8). The pluton and the Calamiti schists are topped by the Zuccale low-angle normal fault that cuts down-section across the entire nappe stack with clear evidence of top-to- 

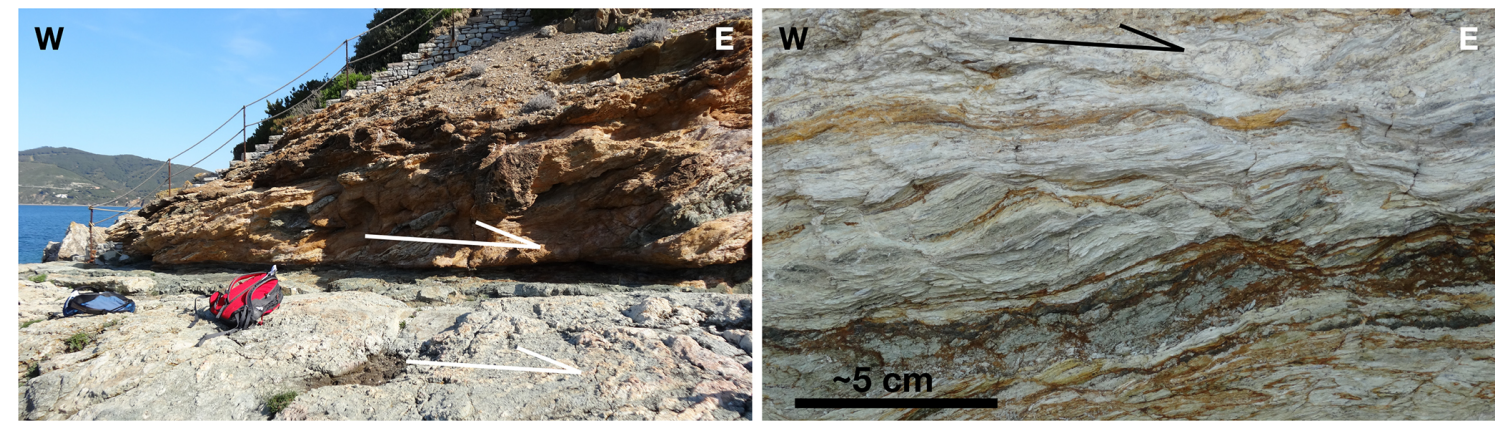

Figure 9. Left: overview of the detachment fault. Right: detail of the shear bands indicating top-to-the-east kinematics.

the-east shearing (Fig. 9) (Keller and Pialli, 1990; Keller et al., 1994; Collettini and Holdsworth, 2004).

The main facies of the Monte Capanne pluton exhibits a constant, peraluminous, monzogranitic composition (Poli et al., 1989; Dini et al., 2002; Gagnevin et al., 2004), while the mafic microgranular enclave (MME) varies from tonaliticgranodioritic to monzogranitic. The leucogranitic dykes are syenogranitic in composition (Poli et al., 1989; Dini et al., 2002; Gagnevin et al., 2004). Poli et al. (1989), Dini et al. (2002) and Gagnevin et al. (2004) proposed a multiphase magmatic emplacement from peraluminous magmas issued from the melting of a metasedimentary basement and hybridized with mantle-derived mafic magmas whose heat supply possibly enhanced wall-rock assimilation. In addition, injection of mantle-derived magma in the Sant'Andrea facies would have triggered extensive fractionation and mixing of the basic magma with the resident monzogranitic mush (Poli and Tommasini, 1991).

The internal magmatic structure of the Monte Capanne pluton has been described based on the abundance of large alkali-feldspar phenocrysts (Farina et al., 2010). Three main facies corresponding to different magma batches emplaced within too short a period to be discriminated according to geochronology are reported with downward fining of grain size (Fig. 7). The largest grain size characterizes the upper Sant'Andrea facies that mainly crops out in the northwest of the pluton, while the finest grain size is observed in the lower San Piero facies cropping out mainly in its eastern part within the zone affected by the most intense shearing. These three facies delineate an asymmetric dome-shaped bulk structure compatible with the general top-to-the-east sense of shear. In the westernmost part of the Monte Capanne pluton near Sant'Andrea mafic products are observed as large enclaves, with evidence of magma mixing and mingling. These mafic enclaves are mostly found in the Sant'Andrea facies that was emplaced first. Their occurrence in the westernmost part of the plutonic body, the farthest from the detachment, with a geometry similar to what is observed on Serifos island in the Cyclades, suggests that they are associated with the root of the pluton.
Assuming that the three main felsic facies correspond to three successive intrusion batches, one observes an evolution toward finer grain size through time, an evolution that is compatible with progressive exhumation and also with a shorter residence time in the magma chamber, suggesting opening of the magmatic plumbing toward the surface leading to volcanic activity, as recorded above the detachment. The last episodes of intrusive activity are seen as a series of felsic dykes striking N-S or NE-SW, due to eastward extensional brittle deformation, while the pluton was at near-solidus conditions.

\subsection{Orientation of K-feldpar megacrysts}

We conducted a detailed study of the orientation of feldspar megacrysts along the shore near Sant'Andrea (Figs. 10, 11, 12). The pluton is there characterized by a high concentration of megacrysts and of mafic enclaves reaching several metres in size. Megacrysts show euhedral shapes in general. Although the orientation of megacrysts is quite stable at the scale of a few hundred metres, in the westernmost region the presence of the large enclaves is associated with a disorientation of the megacrysts (Fig. 11a), indicating increasing tortuosity of the flow wrapping around them associated with local turbulence in pressure shadows. Smaller enclaves are in general aligned with the megacrysts. Some of the mafic enclaves with lobate shapes show a sharp boundary with the felsic matrix, suggesting the quenching of a hot mafic magma within the cooler felsic magma (Fernandez and Barbarin, 1991; Van der laan and Wyllie, 1993; Fernandez and Gasquet, 1994). Other enclaves are less mafic and show evidence of magma mingling-mixing. The disaggregation process of the mafic magma responsible for theses enclaves could have happened either in a deep-seated magmatic chamber (Christofides et al., 2007) or more likely in the ascent conduit as a result of remelting of chilled mafic margins (Fernaìndez and Castro, 2018) and subsequent viscous fingering dynamics (Perugini et al., 2005). Megacrysts contain inclusions of biotite, plagioclase and quartz and show euhedral shapes in general, although a resorption surface has been noticed (Gagnevin et al., 2008). Other enclaves are less 

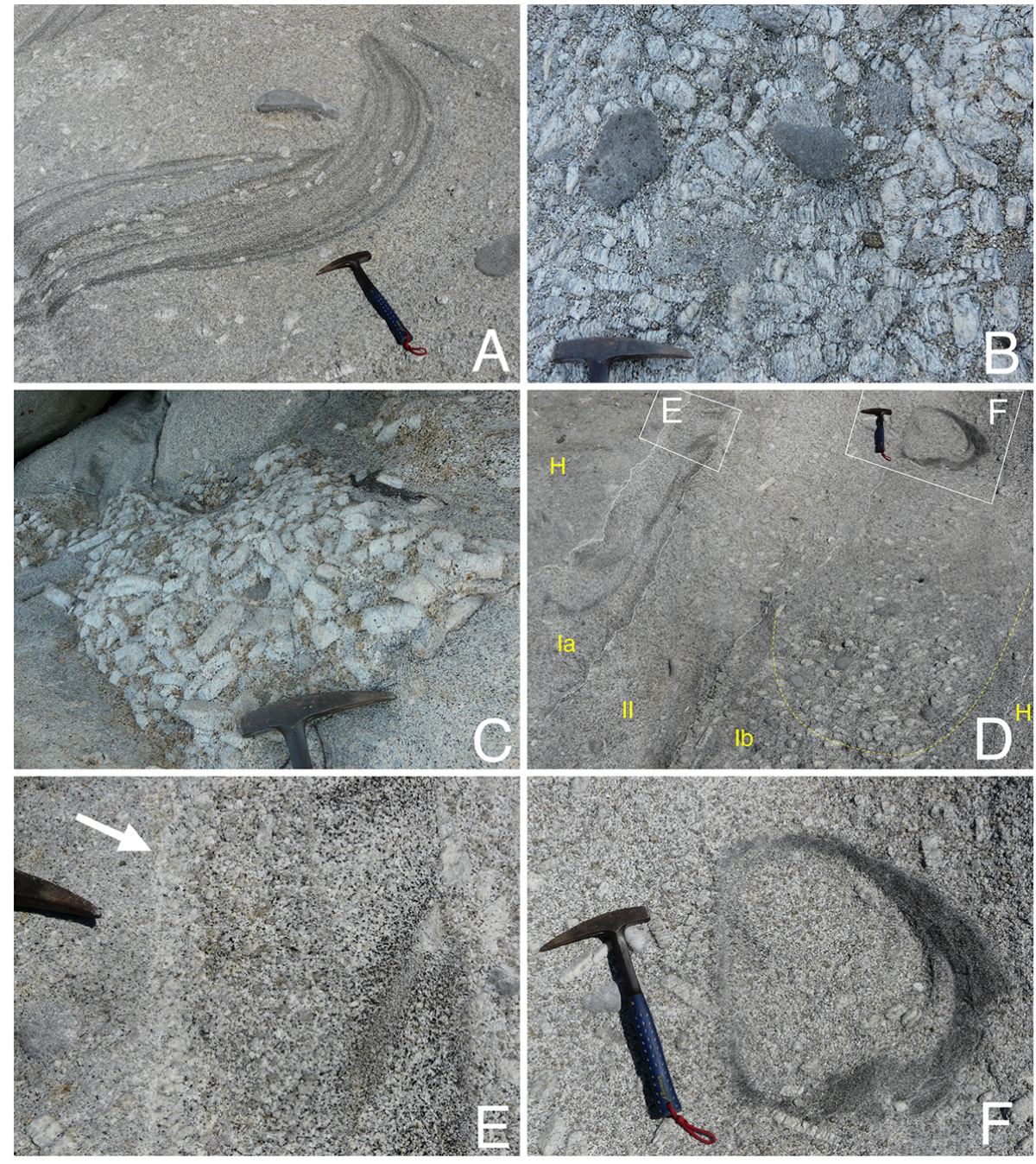

Figure 10. Photographs of the root zone of the Sant'Andrea facies in the melange zone in and around the Cotoncello dyke. (a) Schlieren with cross-bedding. (b) Mush zone with cluster of K-feldspar megacrysts and mafic enclaves. (c) Isolated blob of mush zone with large K-feldspar megacrysts. (d) Folded alternation of leucocratic and melanocratic layers with schlieren. (e) Detail of (d) schlieren. (f) Detail of (d) schlieren tube.

mafic and show evidence of magma mingling-mixing. These enclaves are associated with an aureole where feldspar crystals are concentrated, showing that the assimilation of the enclave occurred at the magmatic stage. Megacrysts are sometimes included within the mafic enclaves, showing that they were already present before the solidification of enclaves and thus providing evidence of a low-viscosity contrast between the enclaves and the host magma at the magmatic stage. All these observations suggest that this western zone is a mixing between a mafic magma of mantle origin and a felsic magma partly issued from crustal anatexy and that this part of the pluton is close to the main feeder. This conclusion is confirmed by AMS (anisotropy of magnetic susceptibility) showing that the magnetic foliation and lineation are steeper there than anywhere else in the pluton (Bouillin et al., 1993).
Further to the east, still within the Sant'Andrea facies, the main granite is intruded by an $\mathrm{N}-\mathrm{S}$ syeno-granitic dyke-like structure near Cotoncello headland, made of a finer-grained facies and a lower concentration of megacrysts and enclaves (Figs. 8d, 10). In its vicinity, the host granite contains folded schlieren with cross-bedding (Fig. 10a). Within these large schlieren, the megacrysts are aligned parallel with the folded foliation of biotite-rich layers. From place to place, decametric megacryst-rich mush zones enriched in decametric and rounded mafic enclaves occur in this host facies (Fig. 10b). In addition, isolated blobs of mush, characterized by an irregular shape, are observed in the coarse-grained, megacryst-poor domains (Fig. 10c). These blobs originate from the disruption of preexisting mush zones within the root zone by subsequent magma injection as illustrated by a dyke-like structure (Rodríguez and Castro, 2019). This structure is composed 


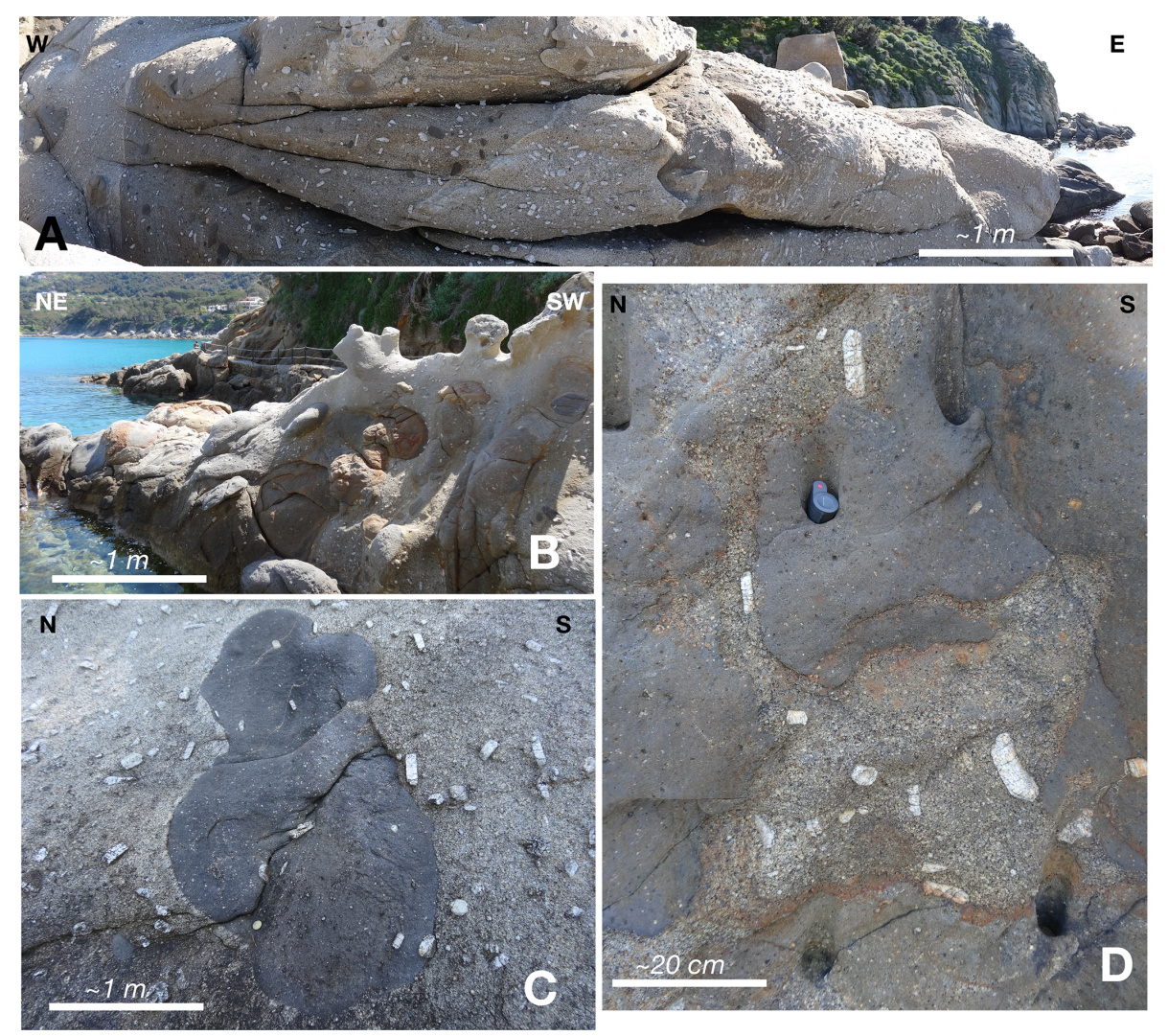

Figure 11. Photographs of large mafic enclaves and melange zones in the westernmost part of the Sant'Andrea facies showing the disorientation of K-feldspar megacrysts and melange facies (mingling).

of three successive injections characterized by undulating and fuzzy boundaries (Fig. 10d). The westernmost injection (injection Ia, Fig. 10d) shows folded alternating leucocratic flow-sorted layers made of quartz, K-feldspar and plagioclase with more melanocratic layers rich in biotite that can be described as schlieren (Fig. 10e). These schlieren are folded and cross-cut by a subsequent and final injection (Fig. 10d, injection II). In the easternmost injection (Fig. 10d, injection Ib), K-feldspar megacrysts are accumulated and their orientation defines a concave upwards foliation. Such mineral fabric is similar to those described by Rocher et al. (2018) in fingerand-drip structures developed at the margins of the Asha pluton (NW Argentina) and interpreted as mechanical accumulation in a downward localized multiphase magmatic flow. In addition, this megacryst accumulation is associated at its top with ring schlieren that could represent a cross section of a schlieren tube (ŽáK and Klomínský, 2007) (Fig. 10f). Ring schlieren are also associated with drip structures in the Asha pluton among others (Paterson, 2009; Rocher et al., 2018). The most external rim between the host body $\mathrm{H}$ and injection Ia (Fig. 10d) is associated with a reaction zone with recrystallization of quartz and K-feldspar (Fig. 10e, white arrow). Outside the injections, the mineral fabric shown by the K-feldspar megacrysts tends to reorient itself parallel to the rims. All these observations point to an injection of a low-viscosity, crystal-poor, magma with a viscosity contrast of about 1 order of magnitude lower with respect to its host magma (Wiebe et al., 2017). Mineral fabrics and accumulation and folded and ring schlieren indicate that the structures were formed by localized multiphase magmatic flow when the crystallizing host magma remained partially molten, probably containing around $50 \%$ of crystals (Weinberg et al., 2001). The Cotoncello dyke-like structure is thus co-magmatic with the Sant'Andrea facies, but the pluton was already crystallized enough to allow the formation of $\mathrm{N}-\mathrm{S}$ cracks in the crystal mush capable of transmitting tectonic stress where the magma was injected.

Between the Cotoncello dyke and the root zone to the west, the proportion of enclaves and megacrysts is high everywhere. Systematic measurements of feldspar megacrysts were made (Fig. 12). Mineral foliation and lineation represent the main orientation distributions of the orientation of (010) faces and [001] major axes of the measured crystals, respectively. At the scale of a few hundred metres the fabric shows a consistent pattern with a low-angle north-dipping foliation more prominent in regions poorer in mafic enclaves. The lineation is on average E-W trending. Late mafic and acidic dykes strike perpendicular to the lineation. Within 


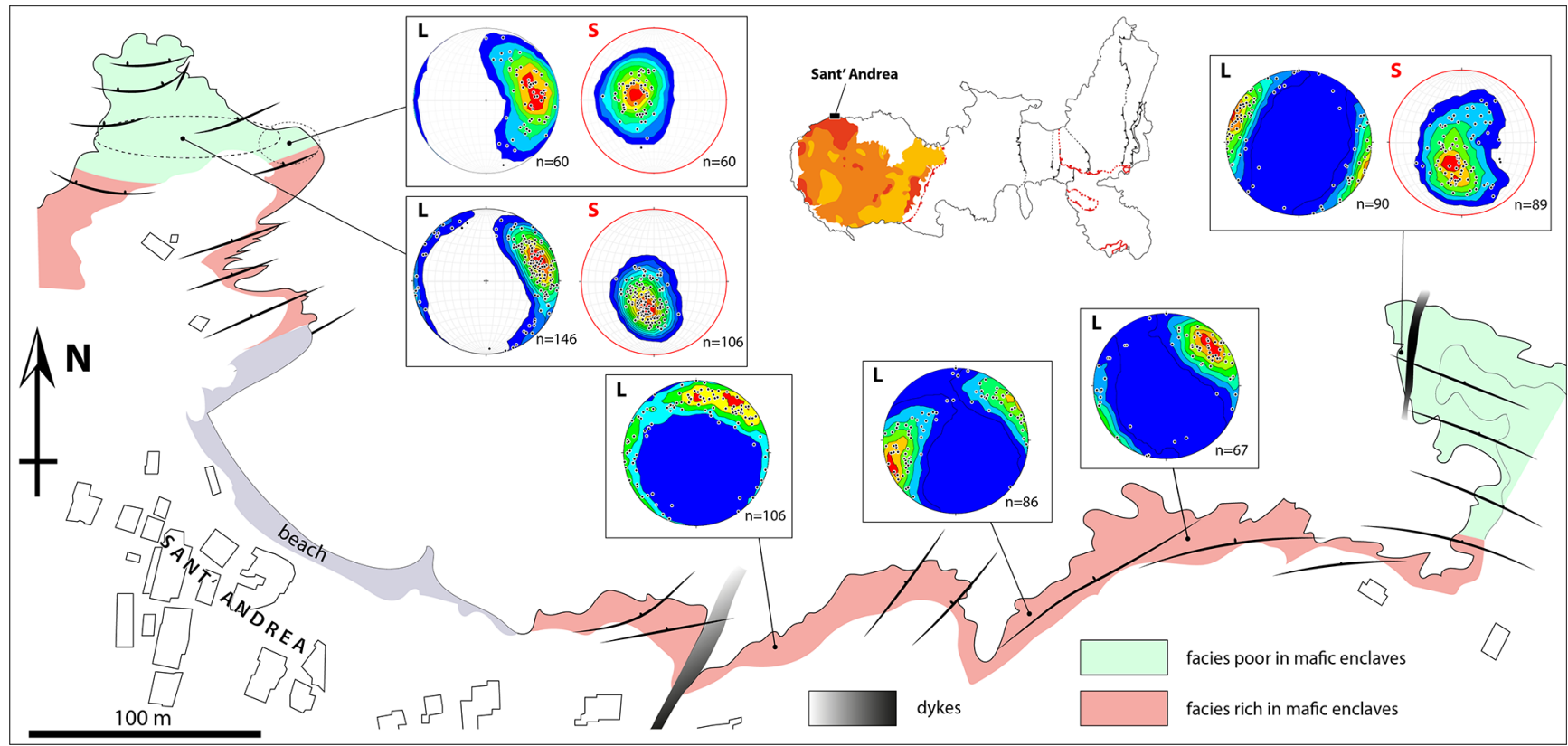

Figure 12. Detailed study of the orientation of K-feldspar megacrysts in the Sant-Andrea facies with foliation trajectories.

the mélange zone the mineral fabric is often perturbated approaching enclave swarms. Then, the fabric becomes more uniform with variations around an average ENE-WSW trend from $\mathrm{N} 30$ to $\mathrm{N} 100^{\circ} \mathrm{E}$ for the long axes of megacrysts.

As the megacrysts were formed in early magmatic conditions (Vernon, 1986; Vernon and Paterson, 2008), they were in suspension within the melt. Such a preferential orientation is due to a rigid rotation of isolated crystals within a viscous matrix submitted to magmatic flow (Fernandez and Laporte, 1984). In the present case, the various observations attesting to a co-magmatic fabric show that the preferential orientation of the megacryst foliation results from fossilization of the magmatic flow. The large-scale variations in the foliation attitude suggest in addition that the E-W to ENE-WSW flow was laminar in general, except in the immediate vicinity of the large enclaves where the flow wrapping around these stronger bodies was more turbulent.

These detailed observations show that the internal magmatic fabric of the pluton is similar in orientation with its overall tectonic fabric, including the sub-solidus deformation along the eastern margin due to the detachment with a main stretching direction oriented WNW-ESE, as shown by magnetic susceptibility studies (Bouillin et al., 1993) and deformation features near the main eastern contact within the eastern extensional shear zone (Daniel and Jolivet, 1995). This focussing of the pluton fabric, from the magmatic stage to the brittle stage around an E-W-stretching direction compatible with the extensional shear along the main detachment, suggests that the magmatic flow was oriented parallel to the main direction of extension active at the crustal scale since the magmatic stage. A continuum is thus observed from the magmatic stage to the sub-solidus deformation and the localization of the detachment, and this continues during the emplacement of the younger Porto Azzuro pluton and the formation of the Zuccale low-angle normal fault.

\section{Discussion and modelling}

\subsection{Synthesis of observations}

The co-axiality of the structures measured in the Monte $\mathrm{Ca}$ panne pluton from its magmatic stage to the tectonic overprint is similar to observations made on the Cycladic plutons, especially Ikaria and Serifos, where a similar gradual transition is observed from the magmatic stage to the localization of strain along the main detachment. The similarity goes further as the root of the pluton shows a mixture of mafic and felsic facies. On Serifos (Fig. 5), field observations show that the root of the pluton is characterized by vertical or steep dykes and some of them are dilacerated by the top-south flow while the magma is still viscous (Rabillard et al., 2015). Moving toward the detachment, the sub-solidus deformation takes over with an N-S-trending stretching lineation and top-south kinematic indicators. A similar evolution can be observed in the Raches pluton of the island of Ikaria in the Cyclades (Laurent et al., 2015). Emplaced below to top-to-the-north detachment, the magma shows a steep foliation in the south far from the detachment, and it flattens toward the north to become parallel to the detachment plane. Evidence of co-magmatic stretching and shearing parallel to the regional stretching direction is observed on the southern side of the pluton and sub-solidus mylonitization and ultra- 


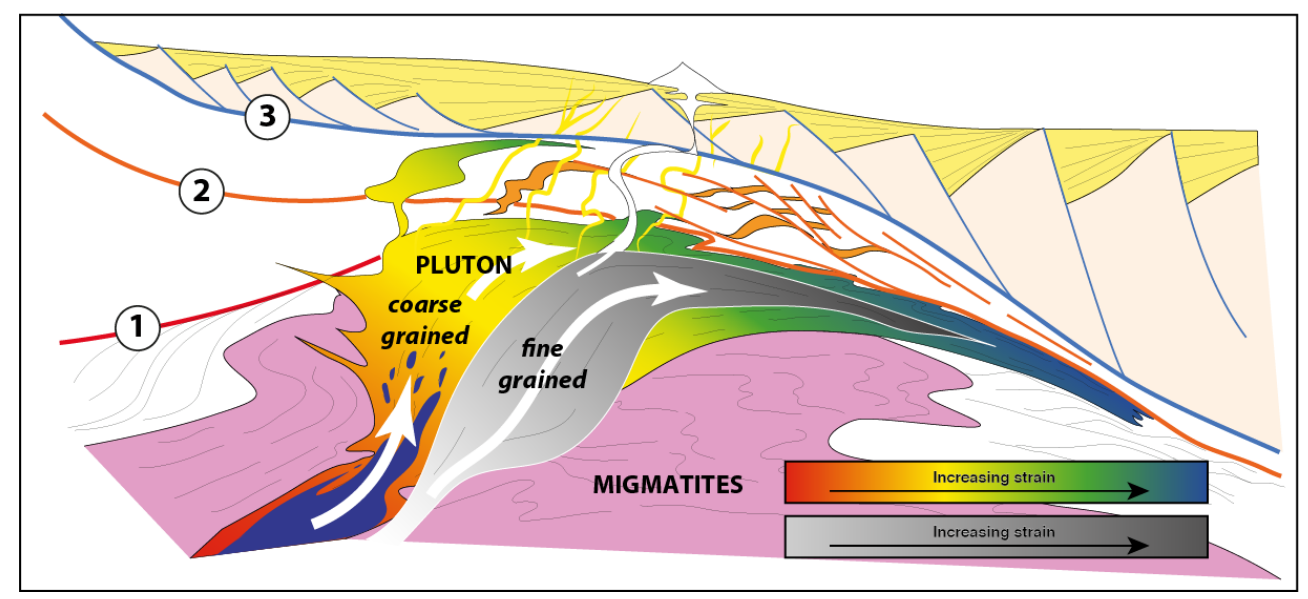

Figure 13. Schematic section showing a conceptual model of the relations between syn-kinematic plutons and the detachments, based on the examples of the Aegean and north Tyrrhenian plutons. Modified from Rabillard et al. (2018).

mylonites on the northern side. A similar situation can be described in the case of the Naxos granodiorite (Bessière et al., 2017). All cases show the syn-kinematic character of the pluton, the best evidence being the syn-kinematic contact metamorphism.

The Monte Capanne pluton thus shows clear similarities with the Aegean plutons. Figure 13 shows a simplified scheme of the geometrical and kinematic relations between detachments and plutons based on the examples of the Aegean and the northern Tyrrhenian Sea, modified from Rabillard et al. (2018). The root zone of the pluton, characterized with an association of mafic and acidic magmas, shows a steeper upward magmatic flow and evidence of comagmatic stretching and shearing parallel to the regional direction of extension with kinematics similar to that of the main detachments. During the emplacement of the pluton, the magma chamber progressively opens toward the surface and the granitoids evolve toward finer-grained facies. Progressive extension and exhumation are accompanied by the inflation of the pluton and injection of dykes across the ductile detachment. New detachments are formed above sequentially.

At the scale of the island of Elba, the sequential intrusion of the Capanne Pluton and the Porto Azzuro pluton associated with the sequential formation of the Capanne Shear Zone followed by the Zuccale Fault is reminiscent of the migration of detachments within the NCDS and the WCDS, where the last increment of extension is accommodated by a low-angle brittle detachment, the Mykonos Detachment in the case of the NCDS and the Kavos Kyklopas Detachment in the case of the WCDS. This is another significant similarity between the Aegean and Tyrrhenian plutons.

\subsection{A conceptual model based on published numerical experiments}

This evolution can be compared with numerical models. Thompson and Connolly (Thompson and Connolly, 1995) summarize the three ways of melting lower continental crust as (1) supplying water to the crust to lower the solidus, (2) decreasing pressure and (3) providing additional heat to the lower crust. They also state that extension alone of a thickened crust is unlikely to reach the conditions of lower-crustal melting unless some additional heat is given by the mantle. Back-arc regions above retreating slabs, where the lithosphere is thinned and the asthenosphere advected upward underneath the crust, seem to the first order to fit these conditions.

Schubert et al. (2013) have explored numerically the effect of the injection of molten mafic material in an extending crust. They show that the injection of this hot material in the lower crust will induce melting and trigger the formation of felsic magmas that will then ascend along steep normal faults all the way to the upper crust, forming the observed plutons. This is a situation that can easily be compared with the Aegean or the Tuscan Archipelago, where the granitoids are associated in their root zones with coeval mafic magmas and the felsic plutons ascend along low-angle detachments. In Fig. 14, we propose a further conceptual model based on numerical experiments of post-orogenic extensional deformation with low-angle shear zones (Huet et al., 2011a). In this series of numerical experiments, the thermal gradient and Moho temperature were varied as was the rheological stratification with either a classical rheological stratification or an inverted crustal structure resulting from the formation of the pre-extension nappe stack, the latter setup being used in Fig. 14; see also Labrousse et al. (2016) for more details on the dynamics of this system with inverted rheological profiles. This latter choice is designed to mimic the 

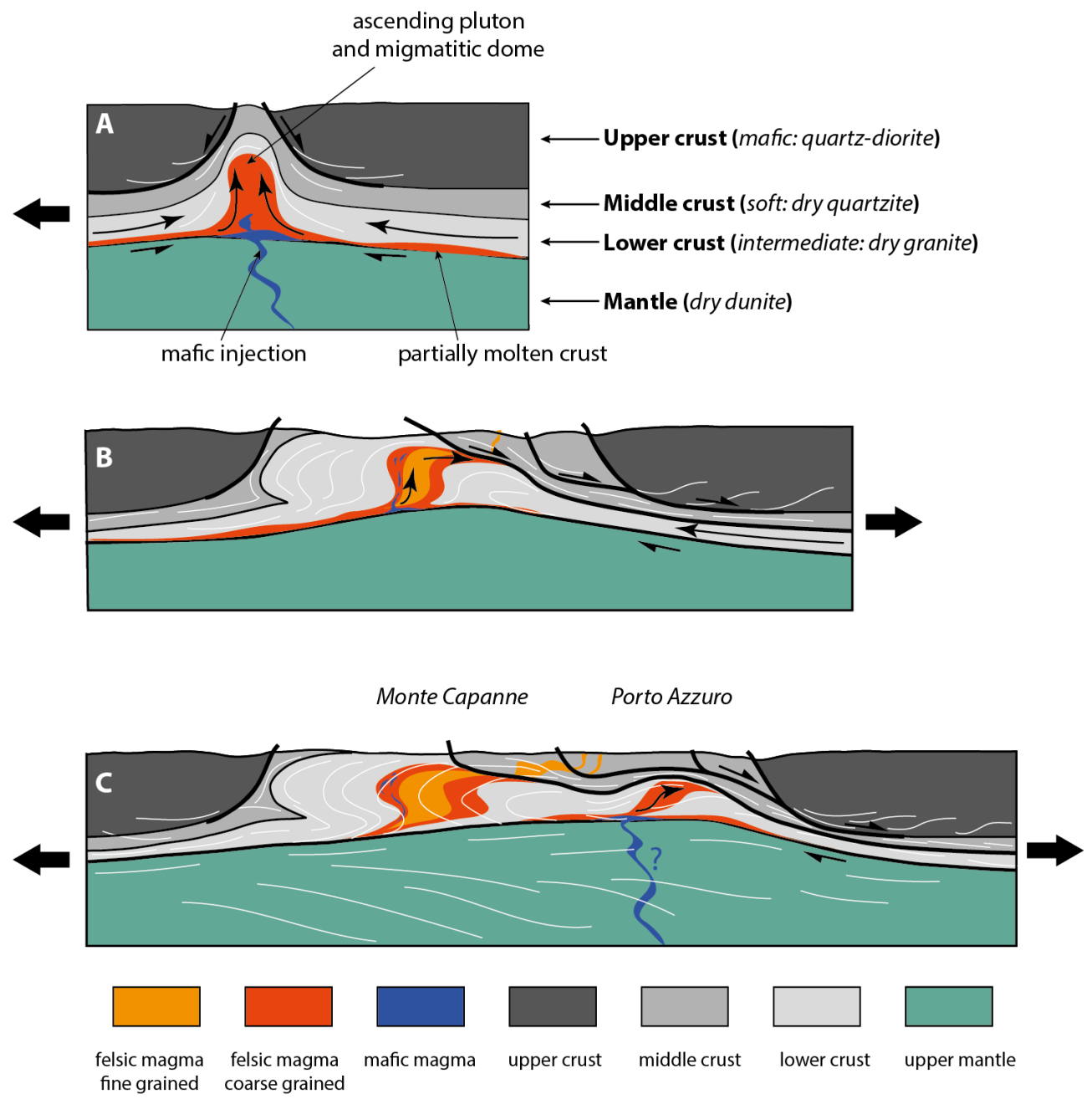

Figure 14. Conceptual model of the succession of events leading to the emplacement of a plutonic system below an active series of detachments, based on Huet et al. (2011) and Schubert et al. (2013).

Aegean orogenic wedge where the Cycladic Blueschist Unit is sandwiched between the Cycladic basement and the Upper Cycladic Unit (UCU) (Huet et al., 2009; Jolivet and Brun, 2010; Ring et al., 2010). The UCU belongs to the Pelagonian paleogeographic domain and is largely composed of an ophiolite, denser and stronger than the Cycladic Blueschist Unit (CBU) (Labrousse et al., 2016), as well as other basement lithologies (Reinecke et al., 1982; Katzir et al., 1996; Soukis and Papanikolaou, 2004; Martha et al., 2016; Lamont et al., 2020). Asymmetric lateral boundary conditions are applied with $1 \mathrm{~cm} / \mathrm{yr}$ on the left side and no displacement of the right side as in Tirel et al. (2004). The upper surface is free and the base is driven by hydrostatic forces. No prescribed discontinuity is introduced in the model; strain localization is only due to the use of random noise in the cohesion value of the upper crust (for more details, see Huet et al., 2011a). The results shown here represent a case where the rheological stratification is inverted and the thermal gradient is high, a likely situation in the Aegean or Tyrrhenian post-orogenic and back-arc contexts.

The conceptual model of the interactions between the numerical model dynamics and the intrusions is that we assume that a batch of mafic magmas, issued from partial melting of the mantle, is injected at the base of the lower crust where it triggers the melting of felsic materials. This leads to the formation of migmatites and the collection of the felsic melts in a rising pluton progressively caught in the detachment dynamics as it reaches the upper parts of the crust. The felsic magma is thus deformed while it is still partly liquid and then mylonitized once it has cooled down below the solidus. While extension proceeds, the overburden is removed by the activity of the detachment and the molten material that comes next is injected in lower pressure conditions and finds a faster access to the surface because of extension, thus leading to smaller grain size plutonic facies and probable volcanism at the surface. While the system of detachments migrates toward the right and a new dome forms, the same situation can 


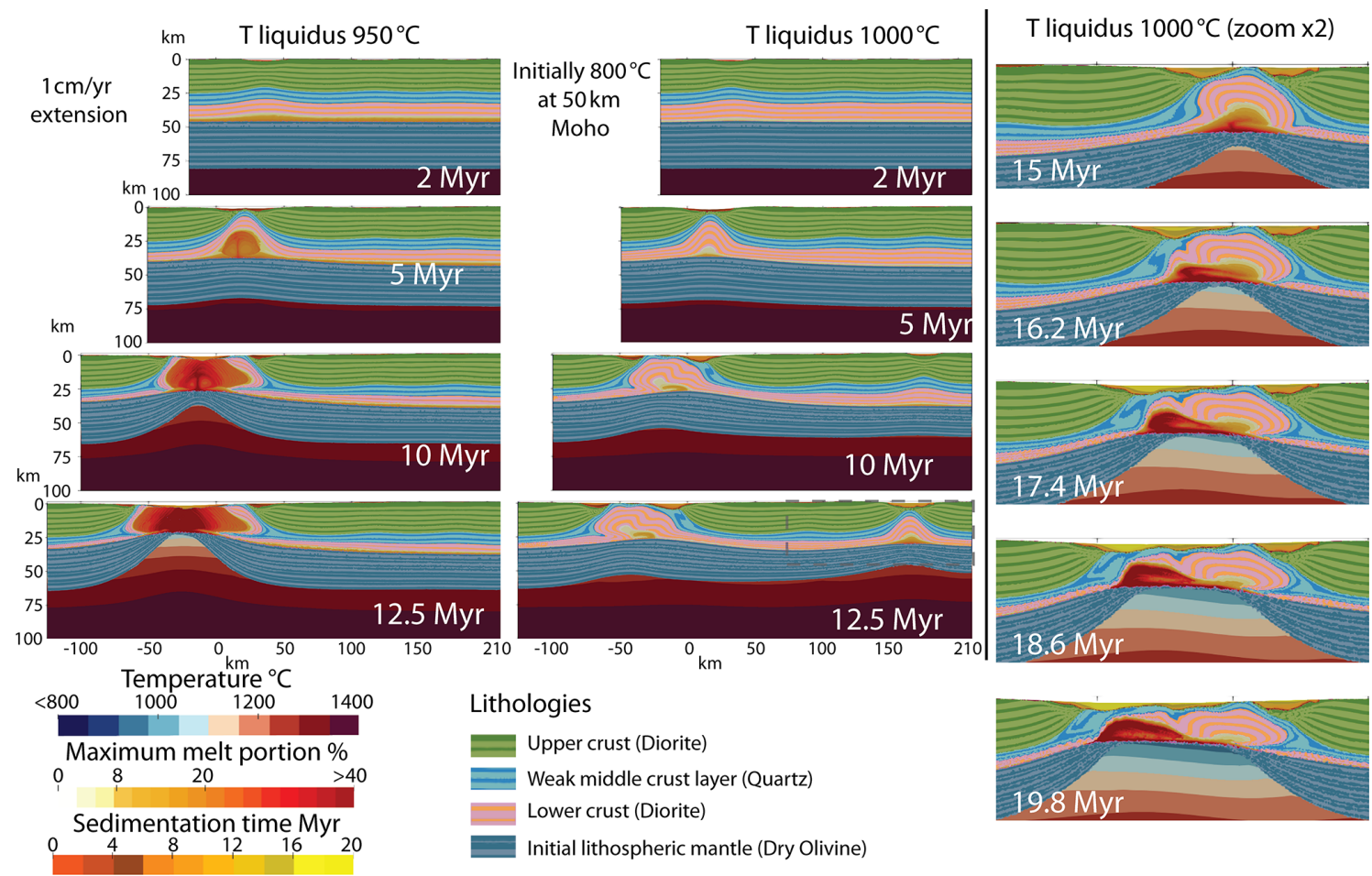

Figure 15. Snapshots of the numerical experiments with two different liquidus temperatures ( 950 and $1000{ }^{\circ} \mathrm{C}$ ) from 2 to $12.5 \mathrm{Ma}$.

be reproduced and a new pluton is emplaced below a detachment further to the right, closer to the active detachment. This evolution is reminiscent of the evolution of the island of Elba with the formation of the Monte Capanne pluton in a first stage and the Porto Azzuro pluton at a later stage.

\subsection{Testing the concept with a new numerical experiment}

Quantitative data on the depth of intrusion of the Monte Capanne pluton can be obtained through the analysis of the metamorphic parageneses in the contact aureole and also assessed by comparison with the nearby Porto Azzurro pluton or the active geothermal field of Larderello. The Porto Azzurro pluton, more recently, induced the formation of a high-temperature contact metamorphism in the Calamiti schists cropping out underneath the Zuccale Fault. Estimations of the pressure-temperature $(P-T)$ conditions of this metamorphism suggest that the pluton was emplaced at a similar depth of about $6.5 \mathrm{~km}$ and the maximum temperature recorded in the schists is about $650{ }^{\circ} \mathrm{C}$ fringing the muscovite breakdown reaction (Caggianelli et al., 2018; Rochira et al., 2018). Analysis of the metamorphic aureole also reveals multiple hydrofracturing episodes by boron-rich fluids which can be compared to the present-day fluid circulation at depth in the Larderello geothermal field (Dini et al., 2002, 2008). Thermal modelling of an intrusion rising in the upper crust (Caggianelli et al., 2018; Rochira et al., 2018) allows constraining the size of the pluton to produce the observed thermal anomaly beneath Larderello, but such a model does not allow testing the interactions between the detachment and the rising and cooling pluton. Although evidence of the involvement of transfer faults has been described in the case of the Porto Azzurro pluton (Spiess et al., 2021), we do not address these in our modelling procedure as our model is kept 2-D for the moment.

The conceptual model described above is now tested with new numerical experiments involving the emplacement of magmas like in Schubert et al. (2013), but in a different situation where low-angle detachments form, to see whether the introduction of a low-viscosity material into the model developed by Huet et al. (2011a) would drastically change the system dynamics or not. This has been done for Figs. 15, 16 and 17. The kinematics of exhumation produced by the nappe stacking experiments of Huet et al. (2011a) produce extension along long-lived detachment better resembling the Mediterranean example than diapiric spreading models that are produced by models with no intermediate weak layers as in Tirel et al. (2004, 2008) or Rey et al. (2009). Hence, in order to test how molten rocks interact with detachments, we decided to build on our experience and start from this setup which is a $210 \mathrm{~km}$ wide model domain submitted to $1 \mathrm{~cm} / \mathrm{yr}$ of extension on its left side for $10 \mathrm{Myr}$ or more with an initial lithospheric column constituted of $25 \mathrm{~km}$ upper crust, $10 \mathrm{~km}$ weak middle crust, and $15 \mathrm{~km}$ thick lower crust overlying $40 \mathrm{~km}$ of lithospheric mantle. The Moho located at $50 \mathrm{~km}$ 

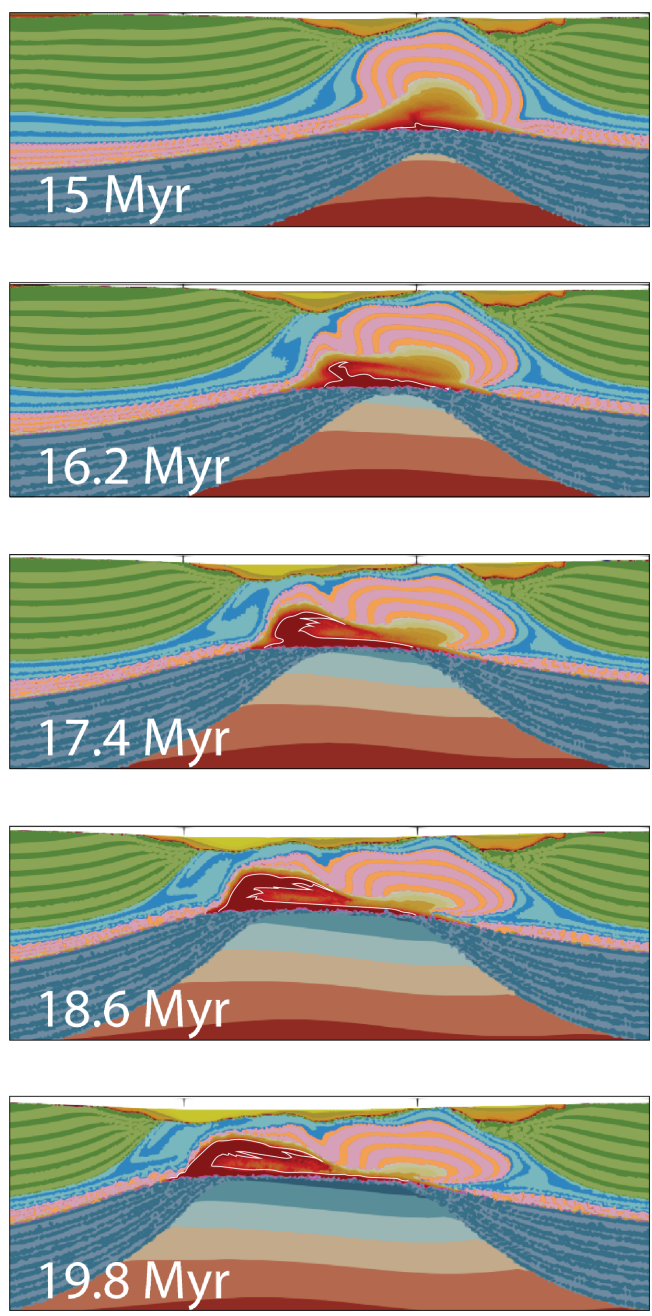

Figure 16. Zoom of the last $5 \mathrm{Myr}$ of evolution of the model of Fig. 15 with a liquidus temperature of $1000^{\circ} \mathrm{C}$ from 15 to $19.8 \mathrm{Ma}$ (black dotted rectangle in Fig. 15 for location).

depth is initially at a temperature of $830^{\circ} \mathrm{C}$. We have taken the same rheological parameters as reported in Table A1 (Appendix A). The four major differences to Huet et al. (2011a) are as follows:

i. erosion and sedimentation applied to the top boundary;

ii. the deforming Wrinkler foundation at the lithosphereasthenosphere boundary (LAB) has been replaced by inflow of asthenospheric material with higher thermal diffusivity to simulate small-scale convection and keep the base of the lithosphere at $1300{ }^{\circ} \mathrm{C}$ during the experiments as was the case in the Huet et al. (2011a) study;

iii. the numerical code used in this study is pTatin2d (May et al., 2014, 2015), which solves the same momentum equation,

$\nabla \sigma=\rho g$, for velocity $v$ as well as heat conservation,

$-\nabla(-\kappa \nabla T+v T)+H=\frac{\partial T}{\partial t}$,

for Temperature $T$ as Huet et al. (2011a); however, it uses an incompressible visco-plastic rheology minimizing the stress between a dislocation creep regime and Drucker-Prager failure,

$$
\begin{gathered}
\nabla \cdot v=0 \\
\sigma=\min \left(\sin \phi+2 C \cos \phi, \dot{\varepsilon}^{\frac{1}{n}} A^{\frac{-1}{n}} e^{\frac{Q+V P}{n R T}}\right),
\end{gathered}
$$

to evaluate an effective viscosity,

$\eta_{\mathrm{r}}=\frac{\sigma}{2 \dot{\varepsilon}}$,

instead of visco-elasto-plastic rheology based on dislocation creep and Mohr-Coulomb failure criteria;

iv. we added a simplified parametrization in order to account for the mechanical effect of a melt in the simulations; the melt fraction $M_{\mathrm{f}}$ has been introduced as a linear function of solidus $\left(T_{\mathrm{S}}\right)$ and liquidus $\left(T_{1}\right)$ temperature,

$M_{\mathrm{f}}=\min \left(\max \left(\frac{T-T_{\mathrm{s}}}{T_{1}-T_{\mathrm{S}}}, 0\right), 1\right)$,

following Gerya and Yuen (2003). Based on melt fraction, the density and viscosity of passive markers are modified following algebraic averaging for density,

$\rho=M_{\mathrm{f}} \rho_{\mathrm{m}}+\left(1-M_{\mathrm{f}}\right) \rho_{\mathrm{r}}$,

and harmonic averaging for viscosity,

$$
\eta=\left(\frac{M_{\mathrm{f}}}{\eta_{\mathrm{m}}}+\frac{1-M_{\mathrm{f}}}{\eta_{\mathrm{r}}}\right)^{-1} \text {. }
$$

The solidus dependence on pressure $P$ (in GPa) is implemented following wet granite solidus of Miller et al. (2003), but we also added a variable temperature offset $\Delta T$ to account for more mafic granitic composition as follows:

$T_{\mathrm{s}}^{\mathrm{c}}=590+\frac{250}{10(P+0.1)}+\Delta T$.

The dependence of liquidus on pressure is modelled following

$T_{1}^{\mathrm{c}}=\left.T_{\mathrm{s}}^{\mathrm{c}}\right|_{P=0}+10+200 P$.

The mantle is also allowed to melt following the Hirshmann et al. (2000) solidus law:

$T_{\mathrm{s}}^{\mathrm{m}}=-5.904 P^{2}+139.44 P+1108.08$,

$T_{1}^{\mathrm{m}}=T_{\mathrm{s}}^{\mathrm{m}}+600$. 

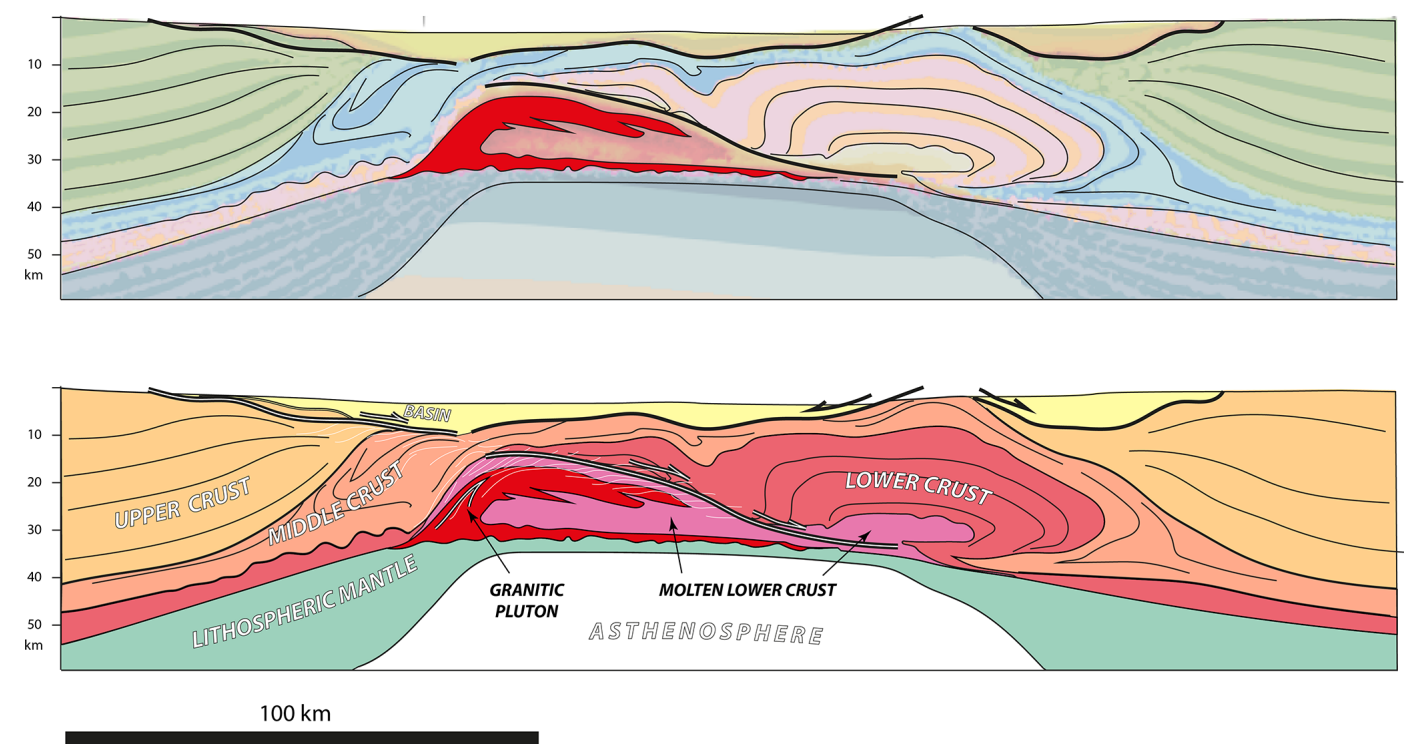

Figure 17. Structural cross section based on the most evolved stage of the numerical model at 19.8 Ma.

All solidus and liquidus temperatures are represented in Fig. A2 (Appendix A) as a function of pressure and temperature. For low melting temperature of the lower crust (wet granite solidus with $\Delta T$ up to $100^{\circ} \mathrm{C}$ ), the crust is largely molten in the initial conditions and buoyancy effects dominate, forming "spreading domes" in the classification of Huet et al. (2011a), and this despite the presence of a weak middle crustal layer. For a higher melting temperature $\left(\Delta T\right.$ from $150^{\circ} \mathrm{C}$ ) the melt proportion remains below the $8 \%$ melt connectivity threshold described by Rosenberg and Handy (2005) during most of the simulation. We interpret elements with markers that never crossed that critical threshold as migmatites. In that case, melting does not disrupt the typical asymmetric detachment kinematics observed in Elba and in the Cyclades that was well reproduced by the Huet et al. (2011a) study. In the late stage of deformation, when the lithospheric mantle is sufficiently attenuated by boudinage, the temperature of the lower crust reaches a sufficient temperature to melt more generously, generating plutons which we define as markers with a melt portion greater than $40 \%$.

With a temperature of $950^{\circ} \mathrm{C}$ at the surface for the liquidus, the molten layer is initially thicker (Fig. 14) and strain develops into a spreading dome geometry like in the models of Tirel et al. $(2004,2008)$ or Rey et al. (2009), with a symmetric strain pattern and limited strain localization. Shear is indeed progressively relocalized on newly formed shear zones at the top of newly exhumed hot material at the structure axis. When the temperature of the liquidus is higher, reaching $1000^{\circ} \mathrm{C}$ in surface conditions (Fig. 15), the molten layer is initially thinner, the deformation is persistently more localized on a detachment on one edge of the dome structure and the model evolves with a detachment on the side of a dome with a limited rate of partial melting in the lower crust $(<8 \%)$. The deformation ultimately migrates to form a second dome where a syn-kinematic low-viscosity body develops with a melt ratio $>40 \%$, which we interpret as analogue to a granite intrusion. The late evolution of this second dome shows a strongly asymmetric geometry with the shape of the syn-kinematic intrusion controlled by the asymmetry in strain pattern and a low-angle shear zone (Fig. 16). Figure 17 shows a structural interpretation of the final step of the model for the second dome highlighting this asymmetry: the dome is bounded by two antithetic crustal-scale persistent shear zones, with a steep and shallow dip, and an eccentricity of the intrusion feeding pipe within the dome. This overall asymmetrical strain and intrusion localization in the case of limited partial melting rate hence reproduces the main features of the strain and intrusion pattern described in the field in the Cyclades and Elba.

Although the model does not show the details of the interactions between the dome and the pluton, which involve percolation of melts, drainage through migmatites and dyke swarms, and progressive intrusion of the detachment by the rising granite, the overall geometry and kinematics are similar to the natural case. The observed geometry is better reproduced in runs with higher crustal melting temperatures and limited melt production. Low-temperature melting reactions for the continental crust are the wet solidus and the muscovite dehydration solidus, while biotite and hornblende dehydration melting reactions could represent higher temperature melting reactions (Weinberg and Hasalovaì, 2015). The model does not show the role of mafic injections at the base of the model either. In the case of the Aegean and Monte Capanne, we have postulated that mafic melts, generated by partial melting of the mantle in the arc and back-arc region, intrude the lower crust and trigger the generation of felsic 
melts that then rise within the dome. This is an additional input of heat into the model that would also localize the weakest layers and thus the deformation and likely favour the evolution of the model in the same direction as in the model presented here with a lower melting temperature. Similar evolution can arise with an additional input of water in the lower crust. This water may originate from amphibolerich gabbros (sanukitoides) that could act as water donors enhancing lower-crustal partial melting to further produce secondary I-type granites (Castro, 2020). In the Aegean arc, whereas amphibole bearing, I-type granites (Naxos and Serifos granodiorites among others) likely reassemble secondary I-type granites as described by Castro et al. (2020, and references therein), the origin of this water remains elusive as amphibole-bearing mantle magmas are not yet evidenced in the migmatites.

Castro (2020) pointed out that melting of the lower crust is enhanced by both heat and water supplied by mantle-derived mafic magmas. In particular, partial melting of granulitic components triggered by adding water from a mafic, mantlerelated, component (vaugnerites) can represent the potential origin of secondary I-type granites as demonstrated by the experimental approach (Castro, 2020). Castro (2020) followed the concept of Chappell and Stephens (1988) whereby the possible dual origin of I-type magma stems from primary I-type magmas issued from coeval subduction, while secondary I-type magmas are more likely related to melting of old subduction-related rocks. In the Aegean and Tyrrhenian tectonic settings, there is no evidence so far for the presence in the outcropping migmatitized crust of mafic components such as sanukitoids issued from older subductionrelated rocks in sufficient volume to be the main donors of water. In contrast, there is much evidence of mafic mantlederived magmas, coeval with the I-type granites s.l. described in our study. For example, at the root of the Serifos granodiorite (Aegean Sea), Rabillard et al. (2015) describe mafic dykes disrupted into enclave swarms scattered throughout the whole magmatic body. Injection of mafic hydrous components took place during the whole emplacement period of the pluton that was cross-cut by basaltic dykes while the granite was at near-solidus conditions. Closely similar observations can be done in the Tyrrhenian granitoids.

We thus fully agree with the assumption of Castro (2020) pointing out that the supply of water to the lower crust is a necessary condition to produce I-type granites, but we believe from the previous petrological studies combined with our field observations that the mafic magmas derived from the coeval mantle are the main donors of water during the partial melting of the lower crust. Distinguishing the two Itype granites in both Aegean and Tyrrhenian granitoids can be completed by an extensive geochemical study of major and trace elements as illustrated by the synthesis made by Castro (2020) for I-type granites emplaced in different tectonic settings. This approach is beyond the scope of our study as the origin of the mafic component has no significant direct impact on the interaction between plutons and detachment faults. Nevertheless, we show basic geochemical diagrams to reinforce the interpretations on lower crust melting and the arrival of mantle-derived magmas at the time of extension and dome formation. In order to illustrate the chemical evolution of I-type granites in the Aegean and Tyrrhenian settings, a complementary figure is proposed in Appendix A (Fig. A1) issued from a compilation of geochemical analyses. This $\mathrm{MgO}$ vs. $\mathrm{SiO}_{2}$ Harker diagram clearly shows the classical negative correlation found in I-type hornblende-biotitebearing granites. The microgranular enclaves represent the mafic hydrous melts that reached the upper crust while they mixed/mingled with differentiated melts either during ascent (Fernaìndez and Castro, 2018) or at the base of the magmatic chambers (also illustrated in Serifos granodiorite by Rabillard et al., 2015). Mixing/mingling processes between mafic mantle-derived melts and acid magmas produce composite batholiths (Poli and Tommasini, 1991) as illustrated by the case of the island of Elba magmatic complex shown for comparison (see Dini et al., 2002 for explanation). An additional element should be considered: the asymmetric model of Huet et al. (2011b) or the model shown here are relevant situations for entraining surface fluids down into the lower crust (Mezri et al., 2015), while a symmetrical model with a spreading dome would not be.

The metamorphic parageneses associated with contact metamorphism in the case of Elba suggest a depth of emplacement of the pluton of 4-6 km. In the numerical model, the genesis of the pluton starts in the lower crust at a larger depth. The contact metamorphism observed in the field characterizes the upper part of the pluton after it had risen within the crust, which may explain this apparent contradiction.

One additional factor has not been considered in this study: the heterogeneity of the crust inherited from earlier tectonic events. It has been shown by numerical experiments that dipping heterogeneities in the crust, mimicking structures inherited from nappe stacking, helps localizing deformation, favouring the development of asymmetrical extensional structures and the development of MCCs (Le Pourhiet et al., 2004; Huet et al., 2011b; Lecomte et al., 2011, 2012). Using these sort of initial conditions with melting would also favour the localization of deformation on a single detachment. It may alternatively favour the development of several asymmetric domes with low-angle detachments. Future studies should focus on testing such initial conditions and also test these processes in 3-D.

The comparison of the Aegean and north Tyrrhenian plutons shows that the model of interactions between plutons and detachments proposed by Rabillard et al. (2018) is reproducible in similar contexts in different regions and can thus probably be generalized. The comparison of this field-based conceptual model with numerical models moreover suggests that this conceptual model is physically feasible. It requires the concomitance of post-orogenic extension, i.e. extension set on an orogenic wedge, and a back-arc context to provide 
the necessary heat and water for the generation of magmas in the mantle and the crust. The possibility of a slab tear would be even more favourable as it increases the possibilities of advecting hot asthenosphere directly below the extending crust.

As shown in the 3-D numerical experiments of Roche et al. (2018a), slab retreat and back-arc extension lead to the boudinage of the lithosphere with a spacing of $\sim 100 \mathrm{~km}$ which will then localize the formation of crustal domes and detachments. This type of evolution may explain the formation of the lines of domes observed in the Aegean and the Menderes Massif. Whether the boudinage also focuses the collection of mantle-derived magmas below the domes is a question that should be addressed by further modelling. This question is important also because the interactions between plutons and detachments described here and in Rabillard et al. (2018) may provide guides for geothermal exploration. The case of the Menderes Massif is exemplary of the intimate relations between active geothermal fields and crustalscale detachments (Roche et al., 2018a). The case of the Tuscan Archipelago is partly similar to the geothermal fields of Larderello and Monte Amiata developed above recent shallow plutons in a context of asymmetric extension with topto-the-east low-angle shear zones (Jolivet et al., 1998; Brogi et al., 2003; Rochira et al., 2018). The Monte Capanne and Porto Azzuro plutons on Elba are associated with hydrothermal activities and mineralization (Maineri et al., 2003; Rossetti and Tecce, 2008; Liotta et al., 2015) that make them good exhumed analogues of active geothermal fields, a situation that is found also in the Cyclades with the mineralizations observed on Mykonos or Serifos in the Cyclades (Salemink, 1985; St. Seymour et al., 2009; Menant et al., 2013; Tombros et al., 2015; Ducoux et al., 2016).

\section{Conclusions}

The comparison between the Aegean and Tyrrhenian Miocene plutons shows striking similarities in their interactions with coeval detachments. These plutons were all emplaced underneath low-angle ductile shear zones and brittle detachments in a post-orogenic back-arc environment where extra heat is provided by advected asthenospheric mantle. The roots of those felsic plutons show a mixing with mafic magmas. The magmatic fabric is steep in the vicinity of the roots and shallows toward the detachments. The plutons record substantial stretching and shearing co-axial with the regional deformation while they still contain a significant amount of melt. In sub-solidus conditions, the granitoids are then mylonitized when approaching the detachment until the formation of ultra-mylonites and pseudotachylytes. In both cases too, the felsic magma intrudes into the detachment and invades the upper plate. A migration of detachments is then observed from the deep and ductile detachments to more brittle and surficial ones. Late magmatic batches show a smaller grain size compatible with an opening of the magma chamber toward the surface, suggestive of the volcano-plutonic context of these plutons. To account for these similarities suggesting that this model can be generalized we proposed a conceptual model where mafic magma batches are injected into the lower crust of an extending orogenic wedge in a back-arc region with low-angle detachments. These mafic injections trigger the melting of the lower-crustal felsic material and the ascent of felsic plutons in the crust, controlled by the low-angle detachments. The migration of the detachments through time in the model explains the migration of plutons and detachments observed in the Tuscan Archipelago and in Tuscany from the late Miocene to the late Pliocene as well as in the Aegean. This conceptual model is tested with a numerical approach showing the impact of melt supply in the development of the dome strain pattern. The observed asymmetry of strain localization and intrusion are reproduced for a limited melting rate, while a higher melting rate would lead to the development of a completely different dome structure. The geometry and kinematics observed in the field are well reproduced by the model. These intimate interactions between plutons and detachments can be foreseen as useful guides for the prospection and understanding of geothermal and associated mineralization. 


\section{Appendix A}

Table A1. Values and notation for variable physical parameters. Parameters for dislocation creep come from 1 (Ranalli and Murphy, 1987), 2 (Hansen and Carter, 1982) and 3 (Chopra and Paterson, 1984). Other constant parameters include friction $\varphi$ and cohesion C, which varies linearly with plastic strain in the range $[0,1]$ from 30 to $20^{\circ}$ and from 20 to $2 \mathrm{MPa}$; the coefficients of thermal expansion and compressibility are set to $3 \times 10^{-5} \mathrm{~K}^{-1}$ and $10^{-11} \mathrm{~Pa}^{-1}$

\begin{tabular}{|c|c|c|c|c|c|c|c|}
\hline & & $\begin{array}{r}\text { Sediments } \\
\text { (2) }\end{array}$ & $\begin{array}{r}\text { Upper } \\
\text { crust (1) }\end{array}$ & $\begin{array}{l}\text { Middle } \\
\text { crust(2) }\end{array}$ & $\begin{array}{r}\text { Lower } \\
\text { crust(1) }\end{array}$ & $\begin{array}{r}\text { Lithospheric } \\
\text { mantle (3) }\end{array}$ & $\begin{array}{r}\text { Asthenospheric } \\
\text { mantle (3) }\end{array}$ \\
\hline Density $\left(\mathrm{kg} \mathrm{m}^{-3}\right)$ & $\rho_{\mathrm{r}}$ & 2400 & 2700 & 2700 & 2700 & 3300 & 3300 \\
\hline Pre-exponential factor $\left(\mathrm{MPa}^{-n} \mathrm{~s}^{-1}\right)$ & $A$ & 2.4 & 3.3 & 2.4 & 3.3 & 3.5 & 3.5 \\
\hline Activation energy $(\mathrm{kJ})$ & $Q$ & 156 & 186 & 156 & 219 & 532 & 532 \\
\hline Stress exponent & $n$ & $6.7 \times 10^{-6}$ & $2 \times 10^{-6}$ & $6.7 \times 10^{-6}$ & $1.3 \times 10^{-3}$ & $2.5 \times 10^{4}$ & $2.5 \times 10^{4}$ \\
\hline Melt density $\left(\mathrm{kg} \mathrm{m}^{-3}\right)$ & $\rho_{\mathrm{m}}$ & - & 2400 & 2400 & 2400 & 2800 & 2800 \\
\hline Melt viscosity & $\eta_{\mathrm{m}}$ & - & $10^{17}$ & $10^{17}$ & $10^{17}$ & $10^{12}$ & $10^{12}$ \\
\hline Heat production $\left(\mathrm{W} \mathrm{m}^{-3}\right)$ & $H$ & $1.67 \times 10^{-10}$ & $1.67 \times 10^{-10}$ & 0 & 0 & 0 & 0 \\
\hline Thermal diffusivity & $\kappa$ & $10^{-6}$ & $10^{-6}$ & $10^{-6}$ & $10^{-6}$ & $10^{-6}$ & $5 \times 10^{-6}$ \\
\hline
\end{tabular}




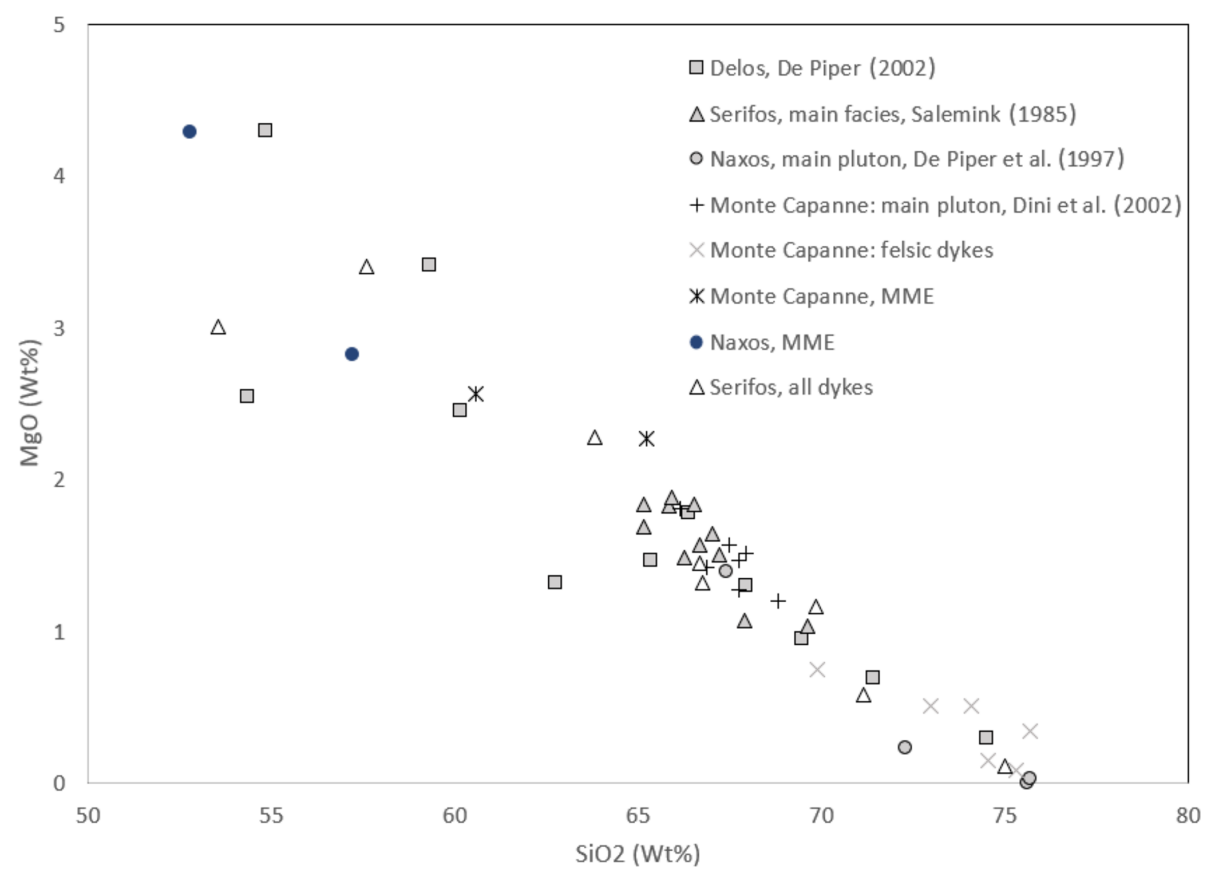

Figure A1. $\mathrm{MgO}$ vs. Si02 Harker diagram showing the negative correlation between whole-rock $\mathrm{MgO}$ and $\mathrm{SiO}_{2}$ content for three I-type, hornblende-biotite-bearing representative Aegean granites. Data from the Delos intrusion (Pe-Piper et al., 2002), Serifos (Salemink, 1985) and Naxos (Pe-Piper et al., 1997). Mixing/mingling processes between mafic mantle-derived melts and acid magmas produce composite batholiths (Poli and Tommasini, 1990) as illustrated by the case of the island of Elba magmatic complex shown for comparison (see Dini et al., 2002, for explanation). MMEs: mafic microgranular enclaves.

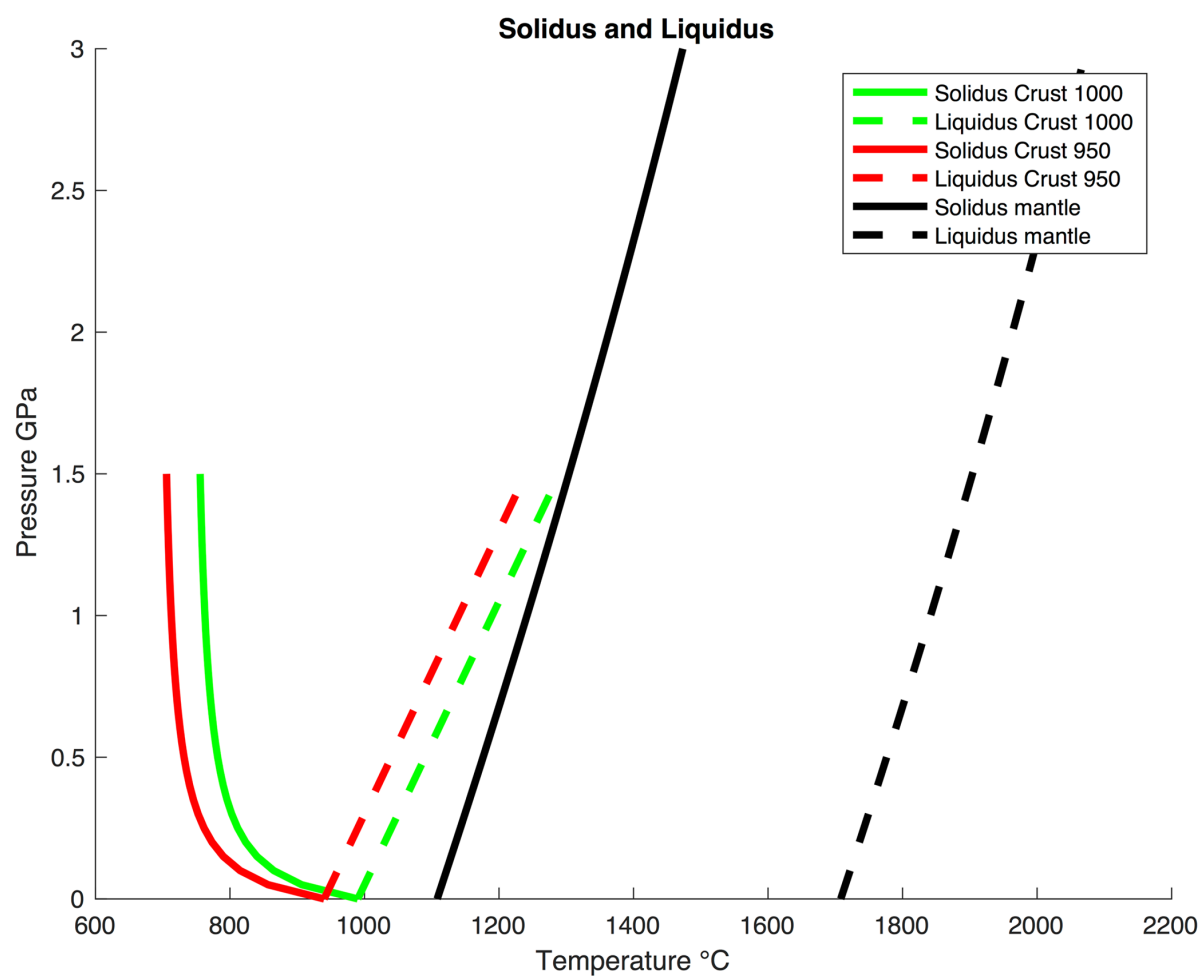

Figure A2. Solidus and liquidus as a function of pressure and temperature for mantle and crust $\left(950\right.$ and $\left.1000^{\circ} \mathrm{C}\right)$. 
Code availability. The numerical code used in this study is opensource and can be downloaded at https://bitbucket.org/ptatin/ ptatin2d/src/master/ (last access: 8 June 2021, May and Le Pourhiet, 2021). Input files are located in the directory published_inputs/Jolivetetal2021SE of May and Le Pourhiet (2021).

Author contributions. LJ, LA, FCG, VR and AR did the field work in the Aegean, and LL and LLP designed the modelling procedure and ran the numerical experiments. All authors contributed to the writing of the paper.

Competing interests. The authors declare that they have no conflict of interest.

Acknowledgements. This paper is a contribution of the ERC Advanced Research Grant RHEOLITH (grant agreement no. 290864) of the Institut Universitaire de France and Labex VOLTAIRE. The paper benefited from the positive suggestions of Antonio Castro and Andrea Brogi, who reviewed the first draft.

Financial support. This paper is a contribution of the ERC Advanced Research Grant RHEOLITH (grant agreement no. 290864) of the Institut Universitaire de France and Labex VOLTAIRE.

Review statement. This paper was edited by Mark Allen and reviewed by Antonio Castro and Andrea Brogi.

\section{References}

Angelier, J., Glaçon, G., and Muller, C.: Sur la présence et la position tectonique du Miocène inférieur marin dans l'archipel de Naxos (Cyclades, Grèce), C. R. Acad. Sc. Paris, 286, 21-24, 1978.

Avanzinelli, R., Lustrino, M., Mattei, M., Melluso, L., and Conticelli, S.: Potassic and ultrapotassic magmatism in the circumTyrrhenian region: Significance of carbonated pelitic vs. pelitic sediment recycling at destructive plate margins, Lithos, 113, 213-227, https://doi.org/10.1016/j.lithos.2009.1003.1029, 2009.

Barberi, F., Giglia, G., Innocenti, F., Marinelli, G., Raggi, G., Ricci, C. A., Squarci, P., Taffi, L., and Trevisan, L.: Carta geologica dell' isola d'Elba scala 1:25000, C. N. R. Roma, 1967.

Bargnesi, E. A., Stockli, D. F., Mancktelow, N., and Soukis, K.: Miocene core complex development and coeval supradetachment basin evolution of Paros, Greece, insights from (U-Th)/He thermochronometry, Tectonophysics, 595, 165-182, 2013.

Beaudoin, A., Augier, R., Laurent, V., Jolivet, L., Lahfid, A., Bosse, V., Arbaret, L., Rabillard, A., and Menant, A.: The Ikaria hightemperature Metamorphic Core Complex (Cyclades, Greece): Geometry, kinematics and thermal structure, J. Geodynam., 92, 18-41, https://doi.org/10.1016/j.jog.2015.1009.1004, 2015.

Berger, A., Schneider, D. A., Grasemann, B., and Stockli, D.: Footwall mineralization during Late Miocene extension along the West Cycladic Detachment System, Lavrion, Greece, Terra Nova, 25, 181-191, 2013.

Berthé, D., Choukroune, P., and Jegouzo, P.: Orthogneiss, mylonite and non coaxial deformation of granites: the example of the South Armorican Shear Zone, J. Struct. Geol., 1, 31-42, 1979.

Bessière, E., Rabillard, A., Précigout, J., Arbaret, L., Jolivet, L., Augier, R., Menant, A., and Mansard, N.: Strain localization within a syn-tectonic intrusion in a back-arc extensional context: the Naxos monzogranite (Greece), Tectonics, 37, https://doi.org/10.1002/2017TC004801, 2018.

Bianco, C., Brogi, A., Caggianelli, A., Giorgetti, G., Liotta, D., and Meccheri, M.: HP-LT metamorphism in Elba Island: Implications for the geodynamic evolution of the inner Northern Apennines (Italy), J. Geodynam., 91, 13-25, https://doi.org/10.1016/j.jog.2015.1008.1001, 2015.

Bianco, C., Godard, G., Halton, A., Brogi, A., Liotta, D., and Caggianelli, A.: The lawsonite- glaucophane blueschists of Elba Island (Italy), Lithos, 348, 105198, https://doi.org/10.1016/j.lithos.2019.105198, 2019.

Bolhar, R., Ring, U., and Allen, C. M.: An integrated zircon geochronological and geochemical investigation into the Miocene plutonic evolution of the Cyclades, Aegean Sea, Greece: Part 1: Geochronology, Contr. Mineral. Petrol., 160, 719-742, 2010.

Bolhar, R., Ring, U., Kemp, A. I. S., Whitehouse, M. J., Weaver, S. D., Woodhead, J. D., Uysal, I. T., and Turnbull, R.: An integrated zircon geochronological and geochemical investigation into the Miocene plutonic evolution of the Cyclades, Aegean Sea, Greece: Part 2: Geochemistry, Contr. Miner. Petrol., 164, 915933, 2012.

Bonin, B.: Do coeval mafic and felsic magmas in post-collisional to within-plate regimes necessarily imply two contrasting, mantle and crustal, sources? A review, Lithos, 78, 1-24, 2004.

Bonini, M. and Sani, F.: Extension and compression in the Northern Apennines (Italy) hinterland: Evidence from the late Miocene-Pliocene Siena-Radicofani Basin and relations with basement structures, Tectonics, 21, 1010, https://doi.org/10.1029/2001TC900024, 2002.

Bouillin, J. P., Poupeau, G., and Sabil, N.: Etude thermochronologique de la dénudation du pluton du Monte Capanne (île d'Elbe, Italie) par les traces de fission, Bulletin de la Société Géologique de France, 165, 19-25, 1994.

Bouillin, J. P., Bouchez, J. L., Lespinasse, P., and Pêcher, A.: Granite emplacement in an extensional setting: an AMS study of the magmatic structures of Monte Capanne (Elba, Italy), Earth Planet. Sc. Lett., 118, 263-279, 1993.

Brogi, A.: The structure of the Monte Amiata volcano-geothermal area (Northern Apennines, Italy): Neogene-Quaternary compression versus extension, Int. J. Earth Sci. (Geol Rundsch), 97, 677703, 2008.

Brogi, A.: Late evolution of the inner Northern Apennines from the structure of the Monti del Chianti-Monte Cetona ridge (Tuscany, Italy), J. Struct. Geol., 141, 104205, https://doi.org/10.1016/j.jsg.2020.104205, 2020.

Brogi, A. and Liotta, D.: Highly extended terrains, lateral segmentation of the substratum, and basin development: The middle-late Miocene Radicondoli Basin (inner northern Apennines, Italy), Tectonics, 27, TC5002, https://doi.org/10.1029/2007TC002188, 2008. 
Brogi, A., Lazzarotto, A., Liotta, D., and Ranalli, G.: Extensional shear zones as imaged by reflection seismic lines: the Larderello geothermal field (central Italy), Tectonophysics, 363, 127-139, 2003.

Brogi, A., Lazzarotto, A., Liotta, D., Ranalli, G., and CROP18 Working Group: Crustal structures in the geothermal areas of southern Tuscany (Italy): Insights from the CROP 18 deep seismic reflection lines, J. Volcanol. Geoth. Res., 148, 60-80, 2005.

Brogi, A., Caggianelli, A., Liotta, D., Zucchi, M., Spina, A., Capezzuoli, E., Casini, A., and Buracchi, E.: The Gavorrano Monzogranite (Northern Apennines): An Updated Review of Host Rock Protoliths, Thermal Metamorphism and Tectonic Setting, Geosciences, 11, 124, https://doi.org/10.3390/geosciences11030124, 2021.

Brown, M.: The generation, segregation, ascent and emplacement of granite magma: the migmatite-to-crustally-derived granite connection in thickened orogens, Earth-Sci. Rev., 36, 83-130, 1994.

Brown, M.: Crustal melting and melt extraction, ascent and emplacement in orogens: mechanisms and consequences, J. Geol. Soc. London, 164, 709-730, 2007.

Brown, M. and Solar, G. S.: Shear-zone systems and melts: feedback relations and self-organization in erogenic belts, J. Struct. Geol., 20, 211-227, 1998.

Brunet, C., Monié, P., Jolivet, L., and Cadet, J. P.: Migration of compression and extension in the Tyrrhenian Sea, insights from ${ }^{40} \mathrm{Ar} /{ }^{39} \mathrm{Ar}$ ages on micas along a transect from Corsica to Tuscany, Tectonophysics, 321, 127-155, 2000.

Buick, I. S.: The late alpine evolution of an extensional shear zone, Naxos, Greece, J. Geol. Soc., 148, 93-103, 1991.

Buick, I. S. and Holland, T. J. B.: The P-T-t path associated with crustal extension, Naxos, Cyclades, Greece, in: Evolution of metamorphic belts, edited by: Daly, J. S., Geol. Soc. Sp., 365369, 1989.

Caggianelli, A., Zucchi, M., Bianco, C., Brogi, A., and Liotta, D.: Estimating P-T metamorphic conditions on the roof of a hidden granitic pluton: an example from the Mt. Calamita promontory (Elba Island, Italy), Ital. J. Geosci., 137, 238-253, 2018.

Camelli, G. M., Dini, I., and D. L.: Upper crustal structure of the Larderello geothermal field as a feature of post-collisional extensional tectonics (southern Tuscany, Italy), Tectonophysics, 224, 413-423, 1993.

Cao, S., Neubauer, F., Bernroider, M., Genser, J., Liu, J., and Friedl, G.: Low-grade retrogression of a high-temperature metamorphic core complex: Naxos, Cyclades, Greece, Geol. Soc. Am. Bull., 129, 93-117, https://doi.org/10.1130/B31502.31501, 2017.

Castro, A.: The dual origin of I-type granites: The contribution from laboratory experiments, in: Post-Archean Granitic Rocks: Petrogenetic Processes and Tectonic Environments, edited by: Janousek, V., Bonin, B., Collins, W. J., Farina, F., and Bowden, P., J. Geol. Soc. London, 43, 365-369, https://doi.org/10.1144/GSL.SP.1989.043.01.32, 2020.

Chappell, B. W. and Stephens, W. E.: Origin of infracrustal (I-type) granite magmas, Transactions of the Royal Society of Edinburgh, Earth Sci., 79, 71-86, https://doi.org/10.1017/S0263593300014139, 1988.

Chopra, P. N. and Paterson, M. S.: The role of water in the deformation of dunite, J. Geophys. Res, 89, 7861-7876, 1984.
Christofides, G., Perugini, D., Koroneos, A., Soldatos, T., Poli, G., Eleftheriadis, G., DelMoro, A., and Neiva, A. M.: Interplay between geochemistry and magma dynamics during magma interaction: an example from the Sithonia Plutonic Complex (NE Greece), Lithos, 95, 243-266, 2007.

Collettini, C. and Barchi, M. R.: A low-angle normal fault in the Umbria region (Central Italy): a mechanical model for the related microseismicity, Tectonophysics, 359, 97-115, 2002.

Collettini, C. and Barchi, M. R.: A comparison of structural data and seismic images for low-angle normal faults in the Northern Apennines (Central Italy): constraints on activity, in: Flow processes in faults and shear zones, edited by: Alsop, G. I., Holdsworth, R. E., McCaffrey, K. J. W., and Hands, M., J. Geol. Soc. London, 491, 101-145, https://doi.org/10.1144/SP4912018-110, 2004.

Collettini, C. and Holdsworth, R. E.: Fault zone weakening and character of slip along low-angle normal faults: insights from the Zuccale fault, Elba, Italy, J. Geol. Soc. London, 161, 1039-1051, 2004.

D’Agostino, N., Chamot-Rooke, N., Funiciello, R., Jolivet, L., and Speranza, F.: The role of pre-existing thrust faults and topography on the styles of extension in the Gran Sasso range (Central Italy), Tectonophysics, 292, 229-254, 1998.

Daniel, J. M. and Jolivet, L.: Detachment faults and pluton emplacement; Elba Island (Tyrrhenian Sea), Bull. Soc. Géol. France, 166, 341-354, 1995.

de Saint Blanquat, M., Horsman, M. E., Habert, G., Morgan, S., Vanderhaeghe, O., Law, R., and Tikoff, B.: Multiscale magmatic cyclicity, duration of pluton construction, and the paradoxical relationship between tectonism and plutonism in continental arcs, Tectonophysics, 500, 20-33, 2011.

Denèle, Y., Lecomte, E., Jolivet, L., Lacombe, O., Labrousse, L., Huet, B., and Le Pourhiet, L.: Granite intrusion in a metamorphic core complex: the example of the Mykonos laccolith (Cyclades, Greece), Tectonophysics, 501, 52-70, 2011.

Dini, A., Mazzarini, F., Musumeci, G., and Rocchi, S.: Multiple hydro-fracturing by boron-rich fluids in the Late Miocene contact aureole of eastern Elba Island (Tuscany, Italy), Terra Nova, 20, 318-326, 2008.

Dini, A., Innocenti, F., Rocchi, S., Tonarini, S., and Westerman, D. S.: The magmatic evolution of the late Miocene laccolithpluton-dyke granitic complex of Elba Island, Italy, Geol. Mag. , 139, 257-279, 2002.

Duchêne, S., Aïssa, R., and Vanderhaeghe, O.: PressureTemperature-time Evolution of Metamorphic Rocks from Naxos (Cyclades, Greece): constraints from Thermobarometry and $\mathrm{Rb} / \mathrm{Sr}$ dating, Geodynamica Acta, 19, 299-319, 2006.

Ducoux, M., Branquet, Y., Jolivet, L., Arbaret, L., Grasemann, B., Rabillard, A., Gumiaux, C., and Drufin, S.: Synkinematic skarns and fluid drainage along detachments: The West Cycladic Detachment System on Serifos Island (Cyclades, Greece) and its related mineralization, Tectonophysics, 695, 126, https://doi.org/10.1016/j.tecto.2016.1012.1008, 2016.

Duggen, S., Hoernle, K., Van den Bogaard, P., and GarbeSchönberg, D.: Post-Collisional Transition from Subductionto Intraplate-type Magmatism in the Westernmost Mediterranean: Evidence for Continental-Edge Delamination of Subcontinental Lithosphere, J. Petrol., 46, 1155-1201, https://doi.org/10.1093/petrology/egi1013, 2005. 
Duranti, S., Palmeri, R., Pertusati, P. C., and Ricci, C. A.: Geological evolution and metamorphic petrology of the sequences of eastern Elba (Complex II), Acta Vulcanologica, Marinelli Volume, 52, 213-229, 1992.

Faccenna, C. and Becker, T. W.: Shaping mobile belts by small-scale convection, Nature, 465, 602-605, https://doi.org/10.1038/nature09064, 2010.

Faccenna, C., Funiciello, F., Giardini, D., and Lucente, P.: Episodic back-arc extension during restricted mantle convection in the Central Mediterranean, Earth Planet. Sc. Lett., 187, 105-116, 2001a.

Faccenna, C., Becker, T. W., Lucente, F. P., Jolivet, L., and Rossetti, F.: History of subduction and back-arc extension in the Central Mediterranean, Geophys. J. Int., 145, 809-820, 2001 b.

Faccenna, C., Becker, T. W., Auer, L., Billi, A., Boschi, L., Brun, J. P., Capitanio, F. A., Funiciello, F., HorvaÌth, F., Jolivet, L., Piromallo, C., Royden, L., Rossetti, F., and Serpelloni, E.: Mantle dynamics in the Mediterranean, Rev. Geophys., 52, 283-332, https://doi.org/10.1002/2013RG000444, 2014.

Farina, F., Dini, A., Innocenti, F., Rocchi, S., and Westerman, D. S.: Rapid incremental assembly of the Monte Capanne pluton (Elba Island, Tuscany) by downward stacking of magma sheets, GSA Bulletin, 122, 1463-1479, https://doi.org/10.1130/B30112.30111, 2010.

Faulds, J. E., Bouchot, V., Moeck, I., and Oguz, K.: Structural control on geothermal systems in Western Turkey: a preliminary report, GRC Transactions, 33, 375-381, 2009.

Faure, M., Bonneau, M., and Pons, J.: Ductile deformation and syntectonic granite emplacement during the late Miocene extension of the Aegean (Greece), Bull. Soc. Géol. France, 162, 3-12, 1991.

Fernandez, A. and Barbarin, B.: Relative rheology of coeval mafic and felsic magmas: nature of resulting interaction processes and shape and mineral fabric of mafic microgranular enclaves, in: Enclaves and Granite Petrology, edited by: Didier, J. and Barbarin, B., Development in Petrology, Elsevier, 263-275, 1991.

Fernandez, A. and Gasquet, D.: Relative rheological evolution of chemically contrasted coeval magmas: example of the Tichka plutonic complex (Morocco), Contribution to Mineralogy and Petrology, 116, 316-326, 1994.

Fernandez, A. and Laporte, D.: Signification of low symmetry in magmatic rocks, J. Struct. Geol., 13, 337-347, 1984.

Fernaìndez, C. and Castro, A.: Mechanical and structural consequences of magma differentiation at ascent conduits: A possible origin for some mafic microgranular enclaves in granites, Lithos, 320, 49-61, https://doi.org/10.1016/j.lithos.2018.1009.1004, 2018.

Ferrara, G. and Tonarini, S.: Radiometric geochronology in Tuscany : results and problems, Rend. Soc. Ital. Min. Petrol., 40, 111-124, 1985.

Finetti, I. R., Boccaletti, M., Bonini, M., Del Ben, A., Geletti, R., Pipan, M., and Sani, F.: Crustal section based on CROP seismic data across the North Tyrrhenian-Northern Apennines-Adriatic Sea, Tectonophysics, 343, 135-163, 2001.

Gagnevin, D., Daly, J. S., and Poli, G.: Petrographic, geochemical and isotopic constraints on magma dynamics and mixing in the Miocene Monte Capanne monzogranite (Elba Island, Italy), Lithos, 78, 157-195, https://doi.org/10.1016/j.lithos.2004.1004.1043, 2004.
Gagnevin, D., Daly, J. S., and Poli, G.: Insights into granite petrogenesis from quantitative assessment of the field distribution of enclaves, xenoliths and K-feldspar megacrysts in the Monte Capanne pluton, Italy, Mineralogical Magazine, 72, 925-940, 2008.

Gagnevin, D., Daly, J. S., Horstwood, M. S. A., and Whitehouse, M. $\mathrm{J}$.: In-situ zircon $\mathrm{U}-\mathrm{Pb}$, oxygen and hafnium isotopic evidence for magma mixing and mantle metasomatism in the Tuscan Magmatic Province, Italy, Earth Planet. Sc. Lett., 305, 45-56, 2011.

Gautier, P. and Brun, J. P.: Crustal-scale geometry and kinematics of late-orogenic extension in the central Aegean (Cyclades and Evvia island), Tectonophysics, 238, 399-424, 1994a.

Gautier, P. and Brun, J. P.: Ductile crust exhumation and extensional detachments in the central Aegean (Cyclades and Evvia islands), Geodinamica Ac., 7, 57-85, 1994b.

Gautier, P., Brun, J. P., and Jolivet, L.: Structure and kinematics of upper Cenozoic extensional detachement on Naxos and Paros (Cyclades Islands, Greece), Tectonics, 12, 1180-1194, https://doi.org/10.1029/1193TC01131, 1993.

Gerya, T. and Yuen, D.: Rayleigh-Taylor instabilities from hydration and melting propel "cold plumes" at subduction zones, Earth Planet. Sc. Lett., 212, 47-62, 2003.

Gola, G., Bertini, G., Bonini, M., Botteghi, S., Brogi, A., De Franco, R., Dini, A., Donato, A., Gianelli, G., LiottIa, D., Manzella, A., Montanari, D., Montegrossi, G., Petracchini, L., Ruggieri, G., Santilano, A., Scrocca, D., and Trumpy, E.: Data integration and conceptual modelling of the Larderello geothermal area, Italy, Energy Procedia, 125, 300 309, https://doi.org/10.1016/j.egypro.2017.1008.1201, 2017.

Grasemann, B. and Petrakakis, K.: Evolution of the Serifos Metamorphic Core Complex, Journal of the Virtual Explorer, 27, 118, 2007.

Hansen, F. D. and Carter, N. L.: Creep of selected crustal rocks at $1000 \mathrm{MPa}$, Trans. Am. Geophys. Union, 63, 437, 1982.

Hirschmann, M. M.: Mantle solidus: experimental constraints and the effects of peridotite composition, Geochem. Geophy. Geosy., 1, 2000GC000070, 2000.

Huet, B., Labrousse, L., and Jolivet, L.: Thrust or detachment? Exhumation processes in the Aegean: insight from a field study on Ios (Cyclades, Greece), Tectonics, 28, TC3007, https://doi.org/10.1029/2008TC002397, 2009.

Huet, B., Le Pourhiet, L., Labrousse, L., Burov, E., and Jolivet, L.: Post-orogenic extension and metamorphic core complexes in a heterogeneous crust: the role of crustal layering inherited from collision. Application to the Cyclades (Aegean domain), Geophysical J. Int., 184, 611-625, 2011a.

Huet, B., Le Pourhiet, L., Labrousse, L., Burov, E., and Jolivet, L.: Formation of metamorphic core complex in inherited wedges: a thermomechanical modelling study, Earth Planet. Sc. Lett., 309, https://doi.org/10.1016/j.eps1.2011.1007.1004, 2011 b.

Innocenti, F., Westerman, D. S., Rocchi, S., and Tonarini, S.: The Montecristo monzogranite (Northern Tyrrhenian Sea, Italy): a collisional pluton in an extensional setting, Geolog. J., 32, 131$151,1997$.

Jansen, J. B. H.: Metamorphism on Naxos, Greece, PhD Thesis, Utrecht University, 1977.

Jolivet, L. and Brun, J. P.: Cenozoic geodynamic evolution of the Aegean region, Int. J. Earth Science, 99, 109-138, https://doi.org/10.1007/s00531-00008-00366-00534, 2010. 
Jolivet, L. and Faccenna, C.: Mediterranean extension and the Africa-Eurasia collision, Tectonics, 19, 1095-1106, 2000.

Jolivet, L., Daniel, J. M., Truffert, C., and Goffé, B.: Exhumation of deep crustal metamorphic rocks and crustal extension in back-arc regions, Lithos, 33, 3-30, https://doi.org/10.1016/00244937(1094)90051-90055, 1994.

Jolivet, L., Lecomte, E., Huet, B., Denèle, Y., Lacombe, O., Labrousse, L., Le Pourhiet, L., and Mehl, C.: The North Cycladic Detachment System, Earth Planet. Sc. Lett., 289, 87-104, https://doi.org/10.1016/j.eps1.2009.1010.1032, 2010.

Jolivet, L., Sautter, V., Moretti, I., Vettor, T., Papadopoulou, Z., Augier, R., Deneile, Y., and Arbaret, L.: Anatomy and evolution of a migmatite-cored extensional metamorphic dome and interaction with syn-kinematic intrusions, the Mykonos-Delos-Rheneia MCC, J. Geodynam., 144, 101824, https://doi.org/10.1016/j.jog.2021.101824, 2021.

Jolivet, L., Augier, R., Faccenna, C., Negro, F., Rimmele, G., Agard, P., Robin, C., Rossetti, F., and Crespo-Blanc, A.: Subduction, convergence and the mode of backarc extension in the Mediterranean region, Bull. Soc. Géol. France, 179, 525-550, 2008.

Jolivet, L., Faccenna, C., Goffé, B., Mattei, M., Rossetti, F., Brunet, C., Storti, F., Funiciello, R., Cadet, J. P., and Parra, T.: Mid-crustal shear zones in post-orogenic extension: the northern Tyrrhenian Sea case, J. Geophys. Res., 103, 12123-12160, https://doi.org/10.11029/12197JB03616, 1998.

Jolivet, L., Menant, A., Sternai, P., Rabillard, A., Arbaret, L., Augier, R., Laurent, V., Beaudoin, A., Grasemann, B., Huet, B., Labrousse, L., and Le Pourhiet, L.: The geological signature of a slab tear below the Aegean, Tectonophysics, 659, 166-182, 2015.

Juteau, M., Michard, A., Zimmermann, J. L., and Albarede, F.: Isotopic heterogeneities in the granitic intrusion of Monte Capanne (Elba island, Italy) and dating concepts, J. Petrol., 25, 532-545, 1984.

Katzir, Y., Matthews, A., Garfunkel, Z., Schliestedt, M., and Avigad, D.: The tectono-metamorphic evolution of a dismembered ophiolite (Tinos, Cyclades, Greece), Geol. Mag., 133, 237-254, 1996.

Keay, S., Lister, G., and Buick, I.: The timing of partial melting, Barrovian metamorphism and granite intrusion in the Naxos metamorphic core complex, Cyclades, Aegean Sea, Greece, Tectonophysics, 342, 275-312, 2001.

Keller, J. V. and Pialli, G.: Tectonics of the island of Elba: a reappraisal, Boll. Soc. Geol. It., 109, 413-425, 1990.

Keller, J. V. A., Minelli, G., and Pialli, G.: Anatomy of late orogenic extension: the Northern Apennines case, Tectonophysics, 238, 275-294, 1994.

Kruckenberg, S. C., Vanderhaeghe, O., Ferré, E. C., Teyssier, C., and Whitney, D. L.: Flow of partially molten crust and the internal dynamics of a migmatite dome, Naxos, Greece: internal dynamics of the Naxos dome, Tectonics, 30, 1-24, https://doi.org/10.1029/2010TC002751, 2011.

Kuhlemann, J., Frisch, W., Dunkl, I., Kázmér, M., and Schmiedl, G.: Miocene siliciclastic deposits of Naxos Island: Geodynamic and environmental implications for the evolution of the southern Aegean Sea (Greece), in: Detrital thermochronology - Provenance analysis, exhumation, and landscape evolution of mountain belts:, edited by: Bernet, M. and Spiegel, C., Special Paper, Geol. Soc. Am., 378, 51-65, 2004.
Labrousse, L., Huet, B., Le Pourhiet, L., Jolivet, L., and Burov, E.: Rheological implications of extensional detachments: Mediterranean and numerical insights, Earth-Sci. Rev., 161, 233-258, 2016.

Lamont, T. N., Roberts, N. M. W., Searle, M. P., Gopon, P., Waters, D. J., and Millar, I.: The age, origin, and emplacement of the Tsiknias Ophiolite, Tinos, Greece, Tectonics, 39, e2019TC00567, https://doi.org/10.01029/02019TC005677, 2020.

Laurent, V., Beaudoin, A., Jolivet, L., Arbaret, L., Augier, R., and Rabillard, A.: Interrelations between extensional shear zones and synkinematic intrusions: The example of Ikaria Island (NE Cyclades, Greece), Tectonophysics, 651, 152-171, 2015.

Le Pourhiet, L., Burov, E., and Moretti, I.: Rifting through a stack of inhomogeneous thrusts (the dipping pie concept), Tectonics, 23, TC4005, https://doi.org/10.1029/2003TC001584, 2004.

Lecomte, E., Le Pourhiet, L., and Lacombe, O.: Mechanical basis for the activity of low angle normal faults, Geophys. Res. Lett., 39, L03307, https://doi.org/10.01029/02011GL050756, 2012.

Lecomte, E., Le Pourhiet, L., Lacombe, O., and Jolivet, L.: A continuum mechanics approach to quantify brittle strain on weak faults: application to the extensional reactivation of shallow-dipping discontinuities, Geophys. J. Int., 184, 1-11, https://doi.org/10.1111/j.1365-1246X.2010.04821.x, 2011.

Lee, J. and Lister, G. S.: Late Miocene ductile extension and detachment faulting, Mykonos, Greece, Geology, 20, 121-124, 1992.

Liotta, D., Brogi, A., Árnadóttir, S., Águìstsson, K., and Thorsteinsdóttir, U.: Field evidence of the interplay between rift and transform structures in the Krafla geothermal area, N-Iceland, Geothermics, 91, 102039, https://doi.org/10.1016/j.geothermics.2020.102039, 2021.

Liotta, D., Brogi, A., Meccheri, M., Dini, A., Bianco, C., and Ruggieri, G.: Coexistence of low-angle normal and high-angle striketo oblique-slip faults during Late Miocene mineralization in eastern Elba Island (Italy), Tectonophysics, 660, 17-34, 2015.

Lister, G. S. and Baldwin, S.: Plutonism and the origin of metamorphic core complexes, Geology, 21, 607-610, 1993.

Lister, G. S. and Snoke, A. W.: S-C mylonites, J. Struct. Geol., 6, 617-638, 1984.

Maineri, C., Benvenuti, M., Costagliola, P., Dini, A., Lattanzi, P., Ruggieri, G., and Villa, I. M.: Sericitic alteration at the La Crocetta deposit (Elba Island, Italy): interplay between magmatism, tectonics and hydrothermal activity, Mineralium Deposita, 38, 67-86, https://doi.org/10.1007/s00126-00002-00279-00122, 2003.

Mantovani, E., Viti, M., Babbucci, D., Tamburelli, C., and Cenni, N.: Geodynamics of the central-western Mediterranean region: plausible and non-plausible driving forces, Mar. Petrol. Geol., 113, 104121, https://doi.org/10.1016/j.marpetgeo.2019.104121, 2020.

Martha, S. O., Dörr, W., Gerdes, A., Petschick, R., Schastok, J., Xypolias, P., and Zulauf, G.: New structural and U-Pb zircon data from Anafi crystalline basement (Cyclades, Greece): constraints on the evolution of a Late Cretaceous magmatic arc in the Internal Hellenides, Int. J. Earth Sci., 105, 2031-2060, https://doi.org/10.1007/s00531-00016-01346-00538, 2016.

Massa, G., Musumeci, G., Mazzrini, F., and Pieruccioni, D.: Coexistence of contractional and extensional tectonics during the northern Apennines orogeny: the late Miocene out-of-sequence 
thrust in the Elba Island nappe stack, Geol. J., 52, 353-368, https://doi.org/10.1002/gj.2761, 2017.

May, D. A. and Le Pourhiet, L.: pTatin2d (Version: https://bitbucket.org/ptatin/ptatin2d/commits/ 991118fb4cdae93cf75859a9b1b96ba43e9bc999?at=restart).

Zenodo, last access: 8 June 2021.

May, D. A., Brown, J., and Le Pourhiet, L.: pTatin3D: Highperformance methods for long-term lithospheric dynamics, in: Proceedings of the International Conference for High Performance Computing, Networking, Storage and Analysis, IEEE Press, 274-284, 2014.

May, D. A., Brown, J., and Le Pourhiet, L.: A scalable, matrix-free multigrid preconditioner for finite element discretizations of heterogeneous Stokes flow, Computer Methods in Applied Mechanics and Engineering, 290, 496-523, 2015.

Mazzarini, F., Musumeci, G., and Cruden, A. R.: Vein development during folding in the upper brittle crust: The case of tourmaline-rich veins of eastern Elba Island, northern Tyrrhenian Sea, Italy, J. Struct. Geol., 33, 1509-1522, https://doi.org/10.1016/j.jsg.2011.1507.1001, 2011.

Menant, A., Jolivet, L., and Vrielynck, B.: Kinematic reconstructions and magmatic evolution illuminating crustal and mantle dynamics of the eastern Mediterranean region since the late Cretaceous, Tectonophysics, 675, 103-140, https://doi.org/10.1016/j.tecto.2016.1003.1007, 2016.

Menant, A., Jolivet, L., Augier, R., and Skarpelis, N.: The North Cycladic Detachment System and associated mineralization, Mykonos, Greece: insights on the evolution of the Aegean domain, Tectonics, 32, 433-452, https://doi.org/10.1002/tect.20037, 2013.

Mezri, L., Le Pourhiet, L., Wolf, S., and Burov, E.: New parametric implementation of metamorphic reactions limited by water content, impact on exhumation along detachment faults, Lithos, 236, 287-298, 2015.

Miller, C. F., McDowell, S. M., and Mapes, R. W.: Hot and cold granites? Implications of zircon saturation temperatures and preservation of inheritance, Geology, 31, 529-532, 2003.

Moeller, S., Grevemeyer, I., Ranero, C., Berndt, C., Klaeschen, D., Sallares, V., Zitellini, N., and de Franco, R.: Early-stage rifting of the northern Tyrrhenian Sea Basin: Results from a combined wide-angle and multichannel seismic study, Geochem. Geophy. Geosy., 14, 3032-3052, 2013.

Moeller, S. I., Grevemeyer, C. R., Ranero, C. R., Berndt, C., Klaeschen, D., Sallares, V., Zitellini, N., and de Franco, R.: Crustal thinning in the northern Tyrrhenian Rift: Insights from multi- channel and wide-angle seismic data across the basin, J. Geophys. Res.-Sol. Ea., 119, 1655-1677, https://doi.org/10.1002/ 2013JB010431, 2014.

Musumeci, G. and Vaselli, L.: Neogene deformation and granite emplacement in the metamorphic units of northern Apennines (Italy): Insights from mylonitic marbles in the Porto Azzurro pluton contact aureole (Elba Island), Geosphere, 8, 470-490, https://doi.org/10.1130/GES00665.00661, 2012.

Musumeci, G., Mazzarini, F., and Cruden, A. R.: The Zuccale Fault,Elba Island, Italy: A new perspective from fault architecture, Tectonics, 34, 1195-1218, https://doi.org/10.1002/2014TC003809, 2015.

Pandeli, E., Giusti, R., Elter, F. M., Orlando, A., and Orti, L.: Structural setting and metamorphic evolution of a contact aureole: the example of the Mt. Capanne pluton (Elba Island, Tuscany, italy), Ofioliti, 43, 41-73, https://doi.org/10.4454/ofioliti.v4443i4451.4455, 2018.

Papeschi, S., Musumeci, G., and Mazzarini, F.: Heterogeneous brittle-ductile deformation at shallow crustal levels under high thermal conditions: The case of a synkinematic contact aureole in the inner northern Apennines, southeastern Elba Island, Italy, Tectonophysics, 717, 547-564, 2017.

Papeschi, S., Musumeci, G., and Mazzarini, F.: Evolution of shear zones through the brittle-ductile transition: The Calamita Schists (Elba Island, Italy), J. Struct. Geol., 113, 100-114, 2018.

Papeschi, S., Musumeci, G., Massonne, H. J., Bartoli, O., and Cesare, B.: Partial melting and strain localization in metapelites at very low-pressure conditions: The northern Apennines magmatic arc on the Island of Elba, Italy, Lithos, 350-351, https://doi.org/10.1016/j.lithos.2019.105230, 2019.

Paterson, S. R.: Magmatic tubes, pipes, troughs, diapirs, and plumes: Late-stage convective instabilities resulting in compositional diversity and permeable networks in crystal-rich magmas of the Tuolumne batholith, Sierra Nevada, California, Geosphere, 5, 496-527, https://doi.org/10.1130/GES00214.00211, 2009.

Pauselli, C. and Ranalli, G.: Effects of lateral variations of crustal rheology on the occurrence of post- orogenic normal faults: The Alto Tiberina Fault (Northern Apennines, Central Italy), Tectonophysics, 721, 45-55, https://doi.org/10.1016/j.tecto.2017.1009.1008, 2017.

Pe-Piper, G.: Origin of S-type granites coeval with I-type granites in the Hellenic subduction system, Miocene of Naxos, Greece, European J. Mineral., 12, 859-875, https://doi.org/10.1127/ejm/1112/1124/0859, 2000.

Pe-Piper, G. and Piper, D. J. W.: The igneous rocks of Greece. The anatomy of an orogen, Gebrüder Borntraeger, Berlin-Stuttgart, 573 pp., 2002.

Pe-Piper, G. and Piper, D. J. W.: Neogene back-arc volcanism of the Aegean: new insights into the relationship between magmatism and tectonics, in: Cenozoic Volcanism in the Mediterranean Area, edited by: Beccaluva, L., and Bianchini, G., Special Paper, Geol. Soc. Am., 17-31, https://doi.org/10.1130/2007.2418(1102), 2007.

Pe-Piper, G., Kotopouli, C. N., and Piper, D. J. W.: Granitoid rocks of Naxos, Greece: regional geology and petrology, Geolog. J., 32, 153-171, https://doi.org/10.1002/(SICI)10991034(199706)199732:199702<199153::AIDGJ199737>199703.199700.CO;199702-199701, 1997.

Pe-Piper, G., Piper, D. J. W., and Matarangas, D.: Regional implications of geochemistry and style of emplacement of Miocene I-type diorite and granite, Delos, Cyclades, Greece, Lithos, 60, 47-66, https://doi.org/10.1016/S0024-4937(1001)00068-00068, 2002.

Perrin, M.: L'ile d'Elbe et la limite Alpes-Apennins: données sur la structure géologique et l'évolution tectogénétique de l'Elbe alpine et de l'Elbe apennine, Bull. Soc. Geol. It., 94, 1929-1955, 1975.

Pertusati, P. C., Raggi, G., Ricci, C. A., Duranti, S., and Palmeri, R.: Evoluzione post-collisionale dell'Elba centro-orientale, Mem. Soc. Geol. It., 49, 297-312, 1993.

Perugini, D., Poli, G., and Rocchi, S.: Development of viscous fingering between mafic and felsic magmas: evidence from the 
Terra Nova Intrusive Complex (Antarctica), Mineral. Petrol., 83, 151-166, 2005.

Petrakakis, K., Iglseder, C., Zámolyi, A., Rambousek, C., Grasemann, B., Draganitis, E., Kurka, A., and Photiades, A.: Serifos Island, Institute of Geology and Mineral Exploration (IGME), Geological Map of Greece, 2010.

Poli, G., Manetti, P., and Tommasini, S.: A petrological review on Miocene-Pliocene intrusive rocks from Southern Tuscany and Tyrrhenian Sea (Italy), Periodico di Mineralogia 58, 109-126, 1989.

Poli, G. E. and Tommasini, S.: Model for the Origin and Significance of Microgranular Enclaves in Calc-alkaline Granitoids, J. Petrol., 32, 657-666, 1991.

Rabillard, A., Arbaret, L., Jolivet, L., Le Breton, N., Gumiaux, C., Augier, R., and Grasemann, B.: Interactions between plutonism and detachments during Metamorphic Core Complex formation, Serifos Island (Cyclades, Greece), Tectonics, 34, 1080-1106, https://doi.org/10.1002/2014TC003650, 2015.

Rabillard, A., Jolivet, L., Arbaret, L., Bessière, E., Laurent, V., Menant, A., Augier, R., and Beaudoin, A.: Synextensional Granitoids and Detachment Systems Within Cycladic Metamorphic Core Complexes (Aegean Sea, Greece): Toward a Regional Tectonomagmatic Model, Tectonics, 37, https://doi.org/10.1029/2017TC004697, 2018.

Ranalli, G. and Murphy, D. C.: Rheological stratification of the lithosphere, Tectonophysics, 132, 281-295, 1987.

Reinecke, T., Altherr, R., Hartung, B., Hatzipanagiotou, K., Kreuzer, H., Harre, W., Klein, H., Keller, J., Geenen, E., and Böger, H.: Remnants of a late Cretaceous high temperature bet on the island of Anafi (Cyclades, Greece), N. Jb. Miner. Abh, 145, 157-182, 1982.

Rey, P. F., Teyssier, C., and Whitney, D. L.: The Role of Partial Melting and Extensional Strain Rates in the Development of Metamorphic Core Complexes, Tectonophysics, 477, 135-144, https://doi.org/10.1016/j.tecto.2009.1003.1010, 2009.

Ring, U.: The geology of Ikaria Island: The Messaria extensional shear zone, granites and the exotic Ikaria nappe, Journal of the Virtual Explorer, 27, 1-32, 2007.

Ring, U., Glodny, J., Will, T., and Thomson, S.: The Hellenic Subduction System: High-Pressure Metamorphism, Exhumation, Normal Faulting, and Large-Scale Extension, Annu. Rev. Earth Planet. Sci., 38, 45-76, https://doi.org/10.1146/annurev.earth.050708.170910, 2010.

Rocchi, S., Westerman, D. S., Dini, A., Innocenti, F., and Tonarini, S.: Two-stage growth of laccoliths at Elba Island, Italy, Geology, 30, 983-986, 2002.

Roche, V., Sternai, P., Guillou-Frottier, L., Menant, A., Jolivet, L., Bouchot, V., and Gerya, T.: Emplacement of metamorphic core complexes and associated geothermal systems controlled by slab dynamics, Earth Planet. Sc. Lett., 498, 322-333, $2018 \mathrm{a}$.

Roche, V., Bouchot, V., Beccaletto, L., Jolivet, L., GuillouFrottier, L., Tuduri, J., Bozkurt, E., Oguz, K., and Tokay, B.: Structural, lithological and geodynamic controls on geothermal activity in the Menderes geothermal Province (Western Anatolia, Turkey), Int. J. Earth Sci., (Geol Rundsch), https://doi.org/10.1007/s00531-00018-01655-00531, 2018b.

Rocher, S., Alasino, P. H., Grande, M. M., Larrovere, M. A., and Patersonc, S. R.: K-feldspar megacryst accumulations formed by mechanical instabilities in magma chamber margins, Asha pluton, NW Argentina, J. Struct. Geol., 112, 154-173, 2018.

Rochira, F., Caggianelli, A., and de Lorenzo, S.: Regional thermo-rheological field related to granite emplacement in the upper crust: implications for the Larderello area (Tuscany, Italy), Geodinamica Ac., 30, 225-240, https://doi.org/10.1080/09853111.09852018.01488912, 2018.

Rodriìguez, C. and Castro, A.: Origins of mafic microgranular enclaves and enclave swarms in granites: Field and geochemical relations, GSA Bull., 131, 635-660, 2019.

Romagny, A., Jolivet, L., Menant, A., Bessière, E., Maillard, A., Canva, A., and Thinon, I.: Detailed tectonic reconstructions of the Western Mediterranean region for the last $35 \mathrm{Ma}$, insights on driving mechanisms, BSGF-Earth Sciences Bulletin, 191, 37, https://doi.org/10.1051/bsgf/2020040, 2020.

Rosenberg, C. L. and Handy, M. R.: Experimental deformation of partially melted granite revisited: implications for the continental crust, J. Metamorph. Geol., 23, 19-28, 2005.

Rossetti, F. and Tecce, F.: Composition and evolution of fluids during skarn development in the Monte Capanne thermal aureole, Elba Island, central Italy, Geofluids, 8, 167-180, 2008.

Rossetti, F., Tecce, F., Billi, A., and Brilli, M.: Patterns of fluid flow in the contact aureole of the Late Miocene Monte Capanne pluton (Elba Island, Italy): the role of structures and rheology, Contrib. Mineral. Petrol., 53, 743-760, https://doi.org/10.1007/s00410 00006-00175-00413, 2007.

Rossetti, F., Balsamo, F., Villa, I. M., Bouybaouenne, M., Faccenna, C., and Funiciello, R.: Pliocene-Pleistocene HT-LP metamorphism during multiple granitic intrusions in the southern branch of the Larderello geothermal field (southern Tuscany, Italy), J. Geol. Soc. London, 165, 247-262, 2008.

Rossetti, F., Faccenna, C., Jolivet, L., Funiciello, R., Goffé, B., Tecce, F., Brunet, C., Monié, P., and Vidal, O.: Structural signature and exhumation P-T-t path of the Gorgona blueschist sequence (Tuscan Archipelago, Italy), Ofioliti, 26, 175-186, 1999.

Ryan, E., Papeschi, S., Viola, G., Musumeci, G., Mazzarini, F., Torgersen, E., Sørensen, B. E., and Ganerød, M.: Syn-orogenic exhumation of high-P units by upward extrusion in an accretionary wedge: Insights from the Eastern Elba nappe stack (Northern Apennines, Italy), Tectonics, 40, e2020TC006348, https://doi.org/10.1029/2020TC006348, 2021.

Salemink, J.: Skarn and ore formation at Serifos, Greece, as a consequence of granodiorite intrusion, Ph.D thesis, University of Utrecht, Netherlands, 232 pp., 1985.

Sanchez-Gomez, M., Avigad, D., and Heiman, A.: Geochronology of clasts in allochthonous Miocene sedimentary sequences on Mykonos and Paros islands: implications for back-arc extension in the Aegean Sea, J. Geol. Soc. London, 159, 45-60, https://doi.org/10.1144/0016-764901031, 2002.

Saupé, F., Marignac, C., Moine, B., Sonet, J., and Zimmermann, J. L.: Datation par les méthodes $\mathrm{K} / \mathrm{Ar}$ et $\mathrm{Rb} / \mathrm{Sr}$ de quelques roches de la partie orientale de l'ile d'Elbe (Province de Livourne, Italie), B. Minéral., 105, 236-245, 1982.

Savelli, C.: Late Oligocene to Recent episodes of magmatism in and around the Tyrrhenian Sea: implication for the process of opening in a young inter-arc basin of intra-orogenic (Mediterranean) type, Tectonophysics, 146, 163-181, 1988. 
Savelli, C.: Tectono-magmatic lineaments and subduction in the central Mediterranean and southern Italy during the past $8 \mathrm{Ma}$, Boll. Soc. Geol. It., 121, 231-242, 2002a.

Savelli, C.: Time-space distribution of magmatic activity in the western Mediterranean and peripheral orogens during the past $30 \mathrm{Ma}$ (a stimulus to geodynamic considerations), J. Geodynam., 34, 99-126, 2002b.

Savelli, C.: Fast Episodes of West- Mediterranean-Tyrrhenian Oceanic Opening and Revisited Relations with Tectonic Setting, Sci. Rep., 5, 14271, https://doi.org/10.1038/srep14271, 2015.

Scheffer, C., Vanderhaeghe, O., Lanari, P., Tarantola, A., Ponthus, L., Photiades, A., and France, L.: Syn- to post-orogenic exhumation of metamorphic nappes: Structure and thermobarometry of the western Attic-Cycladic metamorphic complex (Lavrion, Greece), J. Geodynam., 96, 174-193, 2016.

Schubert, M., Driesner, T., Gerya, T. V., and Ulmer, P.: Mafic injection as a trigger for felsic magmatism: A numerical study, Geochem. Geophy. Geosy., 14, 1910-1928, doi:1910.1002/ggge.20124, 2013.

Serri, G., Innocenti, F., and Manetti, P.: Geochemical and petrological evidence of the subduction of delaminated Adriatic continental lithosphere in the genesis of the Neogene-Quaternary magmatism of central Italy, Tectonophysics, 223, 117-147, 1993.

Seward, D., Vanderhaeghe, O., Siebenaller, L., Thomson, S., Hibsch, C., Zingg, A., Holzner, P., Ring, U., and Duchêne, S.: Cenozoic tectonic evolution of Naxos Island through a multi-faceted approach of fission-track analysis, in: Extending a continent: architecture, rheology and heat budget, edited by: Ring, U., and Wernicke, B., J. Geol. Soc. London, 179-196, 2009.

Soukis, K. I. and Papanikolaou, D. J.: Contrasting geometry between Alpine and Late-to-post-Alpine tectonic structures in Anafi Island (Cyclades), Bulletin of the Geological Society of Greece Vol. 2004, XXXVI, 1688-1696, 2004.

Spakman, W. and Wortel, R.: A tomographic view on Western Mediterranean geodynamics, in: The TRANSMED Atlas - The Mediterranean region from crust to Mantle, edited by: Cavazza, W., Roure, F. M., Spakman, W., Stampfli, G. M., and Ziegler, P. A., Springer, Berlin, Heidelberg, 31-52, 2004.

Spiess, R., Langone, A., Caggianelli, A., Stuart, F. M., Zucchi, M., Bianco, C., Brogi, A., and Liotta, D.: Unveiling ductile deformation during fast exhumation of a granitic pluton in a transfer zone, J. Struct. Geol., 147, 104326, https://doi.org/10.1016/j.jsg.2021.104326, 2021.

St. Seymour, K., Zouzias, D., Tombros, S., and Kolaiti, E.: Geochemistry of the Serifos pluton (Cycladic islands) and associated iron oxide and sulfide ores: Skarn or metamorphosed exhalite deposits?, Neues Jahrbuch für Mineralogie - Abhandlungen, 186, 249-270, 2009.

Thompson, A. B. and Connolly, J. A. D.: Melting of the continental crust: some thermal and petrological constraints on anatexis in continental collision zones and other tectonic settings, J. Geophys. Res., 100, 15565-15579, 1995.

Tirel, C., Brun, J. P., and Burov, E.: Thermo-mechanical modeling of extensional gneiss domes, in: Gneiss domes in orogeny, edited by: Whitney, D. L., Teyssier, C., and Siddoway, C. S., Geological Society of America Special Paper, Boulder, Colorado, 67-78, 2004.
Tirel, C., Brun, J.-P., and Burov, E.:, Dynamics and structural development of metamorphic core complexes, J. Geophys. Res., 113, B04403, https://doi.org/10.1029/2005JB003694, 2008.

Tombros, S. F., St. Seymour, K., Williams-Jones, A. E., Zhai, D., and Liu, J.: Origin of a barite-sulfide ore deposit in the Mykonos intrusion, cyclades: Trace element, isotopic, fluid inclusion and raman spectroscopy evidence, Ore Geology Reviews 67, 139157, 2015.

Trevisan, L.: L'Elba orientale e la sua tettonica scivolamento par gravità, Mem. Instit. Geol. It. Pavia, 70, 435-470, 1950.

Urai, J. L., Shuiling, R. D., and Jansen, J. B. H.: Alpine deformation on Naxos (Greece), in: Deformation mechanisms, Rheology and tectonics, edited by: Knipe, R. J., and Rutter, E. H., Geol. Soc. Sp., 54, 509-522, https://doi.org/10.1144/GSL.SP.1990.1054.1101.1147, 1990.

van der Laan, S. R. and Wyllie, P. J.: Experimental Interaction of Granitic and Basaltic Magmas and Implications for Mafic Enclaves, J. Petrol., 34, 491-517, 1993.

Vanderhaeghe, O.: Structural development of the Naxos migmatite dome, in: Gneiss domes in orogeny, edited by: Whitney, D. L., Teyssier, C., and Siddoway, C. S., Geological Society of America, Boulder, Colorado, 211-227, 2004.

Vanderhaeghe, O., Kruckenberg, S. C., Gerbault, M., Martin, L., Duchene, S., and Deloule, S.: Crustal-scale convection and diapiric upwelling of a partially molten $\mathrm{T}$ orogenic root (Naxos dome, Greece), Tectonophysics 746, 459-469, https://doi.org/10.1016/j.tecto.2018.03.007, 2018.

Vernon, R. H.: K-feldspar megacrysts in granites - phenocrysts, not porphyroblasts, Earth-Sci. Rev., 23, 1-63, 1986.

Vernon, R. H. and Paterson, S. R.: How late are K-feldspar megacrysts in granites?, Lithos, 104, 327-336, 2008.

Viola, G., Torgersen, E., Mazzarini, F., Musumeci, G., van der Lelij, R., Schonenberger, J., and Garofalo, P. S.: New constraints on the evolution of the inner Northern Apennines by K-Ar dating of Late Miocene-Early Pliocene compression on the Island of Elba, Italy, Tectonics, 37, 3229-3243, 2018.

Weinberg, R. F. and Hasalovaì, P.: Water-fluxed melting of the continental crust: A review, Lithos, 212, 158-188, 2015.

Weinberg, R. F., Sial, A. N., and Pessoa, R. R.: Magma flow within the Tavares pluton, Northeastern Brazil: compositional and thermal convection, Bull. Geol. Soc. Am., 113, 508-520, 2001.

Westerman, D. S., Dini, A., Innocenti, F., and Rocchi, S.: Rise and fall of a nested Christmas-tree laccolith complex, Elba Island, Italy, in: Physical geology of high level magmatic systems, edited by: Breitkreuz, C., and Petford, N., J. Geol. Soc. London, 195213, 2004

Westerman, D. S., Innocenti, F., Tonarini, S., and Ferrara, G.: The Pliocene intrusions of the island of Giglio, Mem. Soc. Geol. It., 49, 345-363, 1993.

Wiebe, R. A., Jellinek, A. M., and Hodge, K. F.: New insights into the origin of ladder dikes: Implications for punctuated growth and crystal accumulation in the Cathedral Peak granodiorite, Lithos, 277, 241-258, 2017.

Wortel, M. J. R. and Spakman, W.: Subduction and slab detachment in the Mediterranean-Carpathian region, Science, 290, 1910 1917, 2000. 
Žák, J. and Klomínský, J.: Magmatic structures in the Krkonose-Jizera Plutonic Complex, Bohemian Massif: evidence for localized multiphase flow and smallscale thermal-mechanical instabilities in a granitic magma chamber, J. Volcanol. Geoth. Res., 164, 254-267, https://doi.org/10.1016/j.jvolgeores.2007.1005.1006, 2007. 